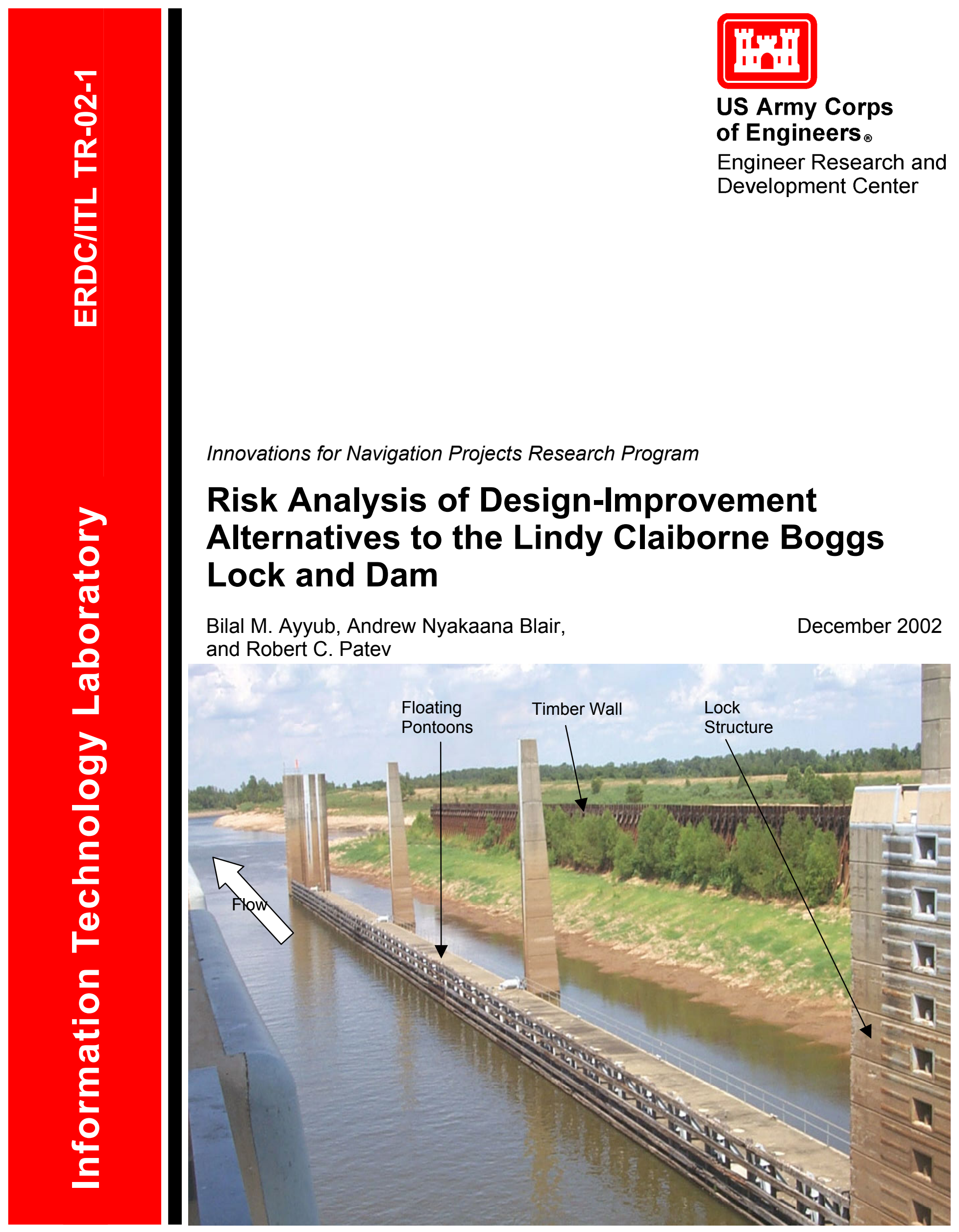


The contents of this report are not to be used for advertising, publication, or promotional purposes. Citation of trade names does not constitute an official endorsement or approval of the use of such commercial products.

The findings of this report are not to be construed as an official Department of the Army position, unless so designated by other authorized documents. 


\section{Risk Analysis of Design-Improvement Alternatives to the Lindy Claiborne Boggs Lock and Dam}

by Bilal M. Ayyub, Andrew Nyakaana Blair

BMA Engineering 11429 Palatine Drive

Potomac, MD 20854-1405

Robert C. Patev

U.S. Army Engineer District, New England 696 Virginia Road

Concord, MA 01742-2751

Final report

Approved for public release; distribution is unlimited

\footnotetext{
Prepared for U.S. Army Corps of Engineers

Washington, DC 20314-1000

Under INP Work Unit 33236

Monitored by Information Technology Laboratory

U.S. Army Engineer Research and Development Center 3909 Halls Ferry Road, Vicksburg, MS 39180-6199
} 


\section{Contents}

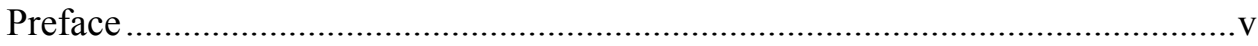

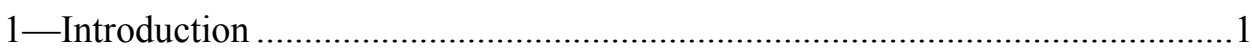

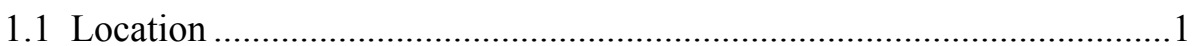

1.2 Problem Description .............................................................. 1

2-Design-Improvement Alternatives for the Lower Lock Approach.................5

2.1 Description of Alternatives .........................................................5

2.1.1 Alternative A: New Fixed Guide Wall with Dike Removal............5

2.1.2 Alternative B: New Fixed Guide Wall with Retention of Dike .....6

2.1.3 Alternative C: Barrier Extension and Use of Concrete Panels ........6

2.2 Assessment of the Alternatives ......................................................6

2.2.1 Alternative A: New Fixed Guide Wall with Dike Removal............7

2.2.2 Alternative B: New Fixed Guide Wall with Retention of Dike ......7

2.2.3 Alternative C: Barrier Extension and Use of Concrete Panels ........8

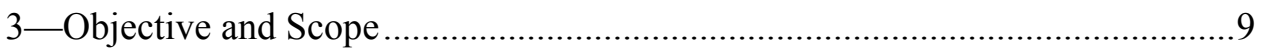

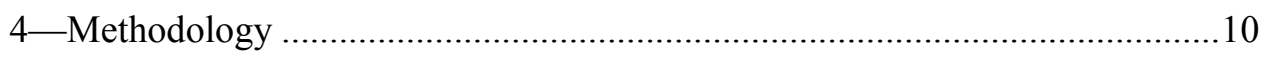

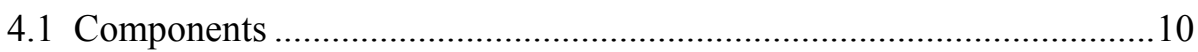

4.2 Definition and Architecture (Primary Logic Boxes) .............................10

5-Data Needs and Collection .......................................................................... 15

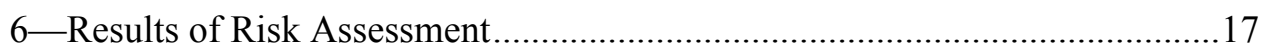

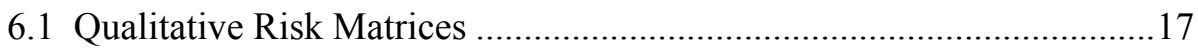

6.2 Expert-Opinion Elicitation..................................................................19

6.3 Risk Assessment of Alternative A .....................................................20

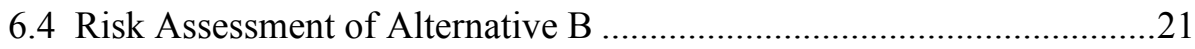

6.5 Risk Assessment of Alternative C .....................................................21

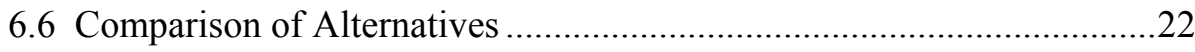

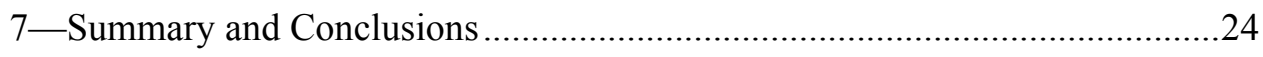

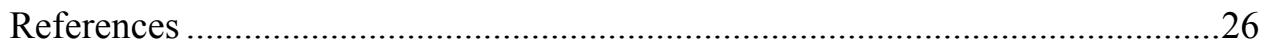

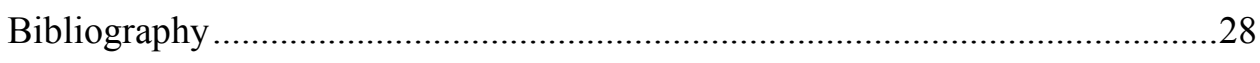

Appendix A: Probabilistic Risk Assessment ...................................................A1

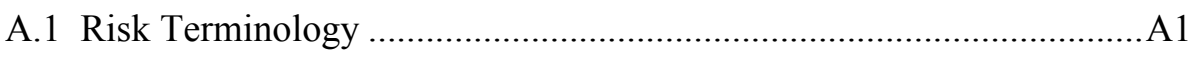

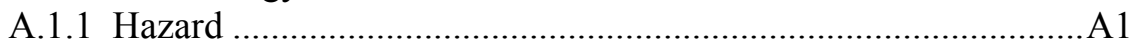




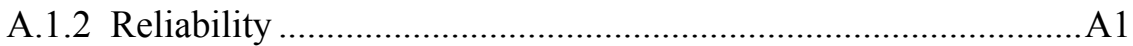

A.1.3 Failure Consequences ...........................................................A2

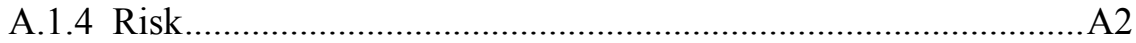

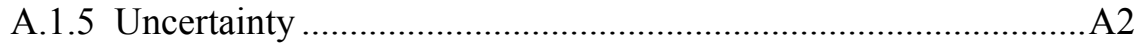

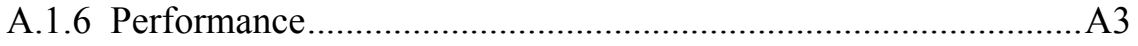

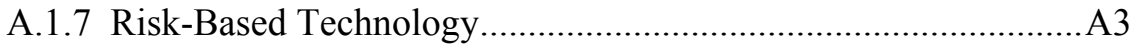

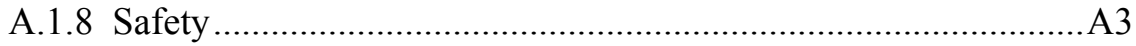

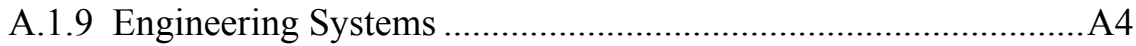

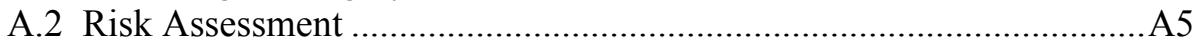

A.3 Typical Probabilistic Risk Analysis Methodology and Its Levels ........A6

A.4 Preliminary Hazard Analysis ..........................................................A8

SF 298 


\section{Preface}

The work described in this report was authorized by Headquarters, U.S. Army Corps of Engineers (HQUSACE), as part of the Innovations for Navigation Projects (INP) Research Program. The work was performed under Work Unit 33236, "Quantifying Risks and Uncertainties of Innovative Construction Techniques." Former and current Principal Investigators are Mr. Robert C. Patev and Dr. Joseph A. Padula of the U.S. Army Engineer Research and Development (ERDC) Information Technology Laboratory (ITL).

Dr. Tony C. Liu was the INP Coordinator at the Directorate of Research and Development, HQUSACE; Research Area Manager was Mr. Barry Holliday, HQUSACE; and Program Monitor was Mr. Mike Kidby, HQUSACE. Mr. William H. McAnally of the U.S. Army ERDC Coastal and Hydraulics Laboratory was the Lead Technical Director for Navigation Systems. Dr. Stanley C. Woodson, ERDC Geotechnical and Structures Laboratory (GSL), was the INP Program Manager. The research was conducted under the supervision of Dr. David W. Pittman, Acting Director of the ERDC GSL, and Dr. Jeffery P. Holland, Director, ITL.

This report was prepared by Drs. Bilal M. Ayyub and Andrew Nyakaana Blair of BMA Engineering, Potomac, MD, and Mr. Patev, currently of the U.S. Army Engineer District (USAED), New England. The work was monitored by Mr. John Burnworth of the USAED, Vicksburg, MS. The authors wish to acknowledge Mr. Burnworth's consistent support and valuable contributions to this research.

Permission to use copyrighted material from the IEEE publication Probabilistic Risk Assessment and Management for Engineers and Scientists was obtained from the Institute of Electrical and Electronics Engineers, Inc.

At the time of publication of this report, Dr. James R. Houston was Director of ERDC, and COL John W. Morris III, EN, was Commander and Executive Director.

The contents of this report are not to be used for advertising, publication, or promotional purposes. Citation of trade names does not constitute an official endorsement or approval of the use of such commercial products. 


\section{Introduction}

\subsection{Location}

The Lindy Claiborne Boggs Lock and Dam facility is located in Catahoula Parish, LA, about 5 miles north of the town of Brouillette. The lock and dam complex is positioned in a 1.7-mile (2.7-km)-long cutoff on the J. Bennett Johnston Waterway between 1967 river miles 42.6 and 51.6. This location is approximately 9 miles $(14 \mathrm{~km})$ upstream from the confluence of the Red and Black Rivers.

\subsection{Problem Description}

The Lindy Claiborne Boggs Lock and Dam is designed to facilitate navigation along the J. Bennett Johnson Waterway between the Mississippi River and Shreveport, LA. Construction of the lock and dam was completed in 1984. A schematic representation of the existing site plan is given as Figure 1, and annotated photographs of the site are provided as Figure 2.

To accommodate the large fluctuation of water levels, floating guide walls upstream and downstream of the lock were incorporated into the plans (U.S. Army Engineer District, Vicksburg 1999). To retain the riverside lock wall backfill, a concrete "T-wall" was constructed for a distance of $130 \mathrm{ft}$ (approximately $40 \mathrm{~m}$ ) perpendicular to the lock on the downstream end. Anticipating that sediment would deposit in the navigation channel underneath the downstream floating guide wall, provisions were provided in the original plans in the form of an earthen dike and a composite "I-wall" (steel sheetpiling and concrete wall) on top of the dike. The I-wall was connected to the T-wall and continued $130 \mathrm{ft}$ offset from and parallel to the floating guide wall for 1,100 ft (335 m). The purpose of the dike and I-wall was to divert the flow and sediment from the floating guide wall and the navigation channel, thus providing a slack-water lock approach channel.

After service began in 1984, the T-wall and the I-wall were inundated and sediment began accumulating beneath the downstream floating guide wall, within the concrete lock monoliths, and in the navigation channel and lock approach. As potential remedy for this problem, the height of the sediment barrier walls was increased from elevation (el) $38.0^{1}$ to el 55.0.

\footnotetext{
1 All elevations (el) cited herein are in feet referenced to the National Geodetic Vertical Datum.
} 


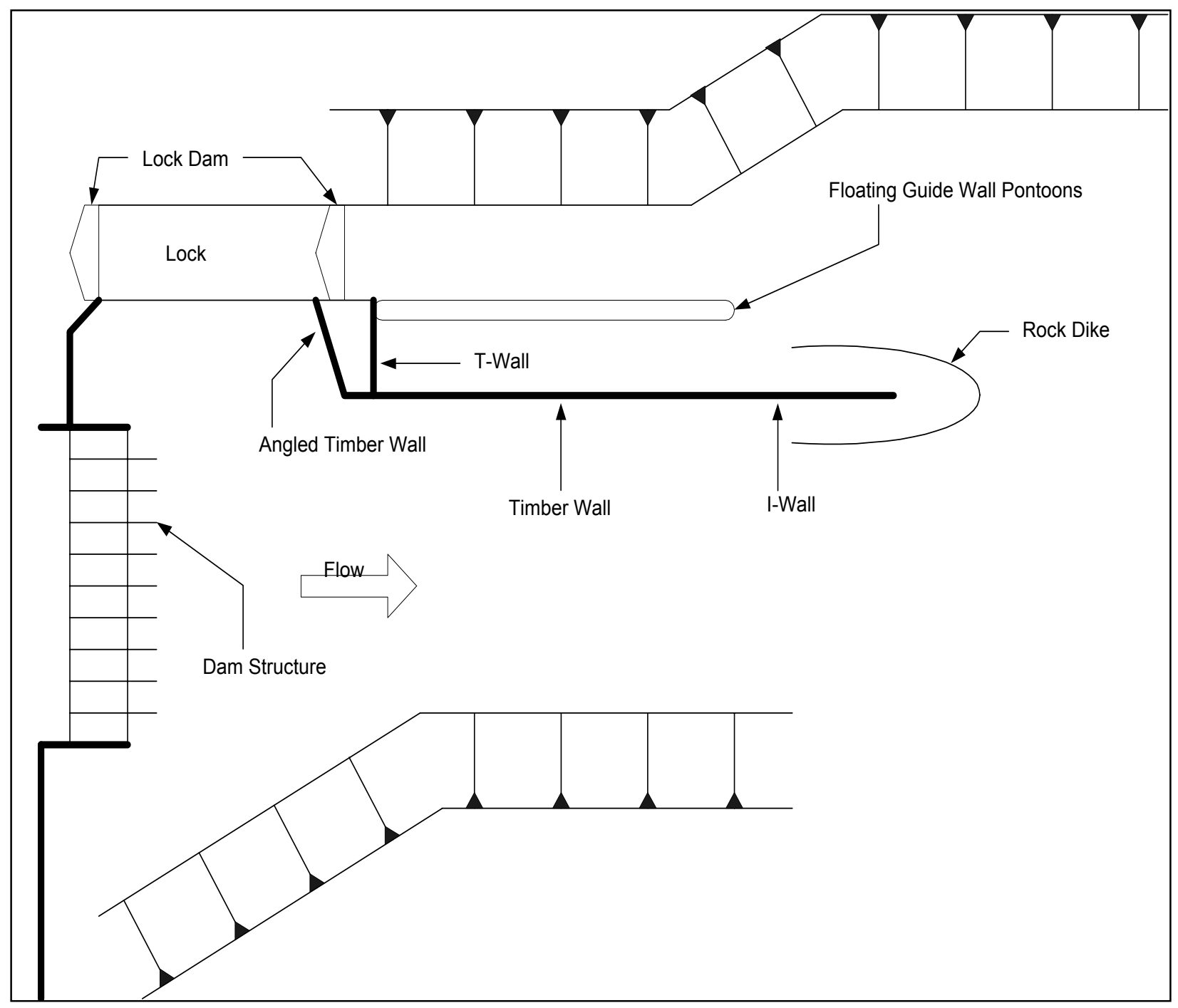

Figure 1. Schematic of existing site (not to scale)

An angled timber wall was constructed upstream of the T-wall, and the I-wall was modified by constructing a timber wall on top of it. These timber walls were completed in 1986. The angled timber wall extends $30 \mathrm{ft}(9 \mathrm{~m})$ from the end of the T-wall upstream and parallel to the lock wall, and then $135 \mathrm{ft}(41 \mathrm{~m})$ back to the lock wall on a 24-deg skew angle. The timber curtain wall constructed on top of the I-wall measured $398 \mathrm{ft}(121 \mathrm{~m})$ from the intersection with the T-wall. The timber wall is supported by a steel H-pile A-frame structure.

After this measure showed that a timber barrier wall could reduce the amount of deposit of sediment within the lock chamber, beneath the floating guide wall, and within the lock approach channel, the timber wall on top of the I-wall was extended an additional $504 \mathrm{ft}(154 \mathrm{~m})$ farther downstream. The extended timber wall (completed in 1988) has proven to be somewhat more effective in reducing the accumulation of sediment, although sedimentation continues to be a problem. 

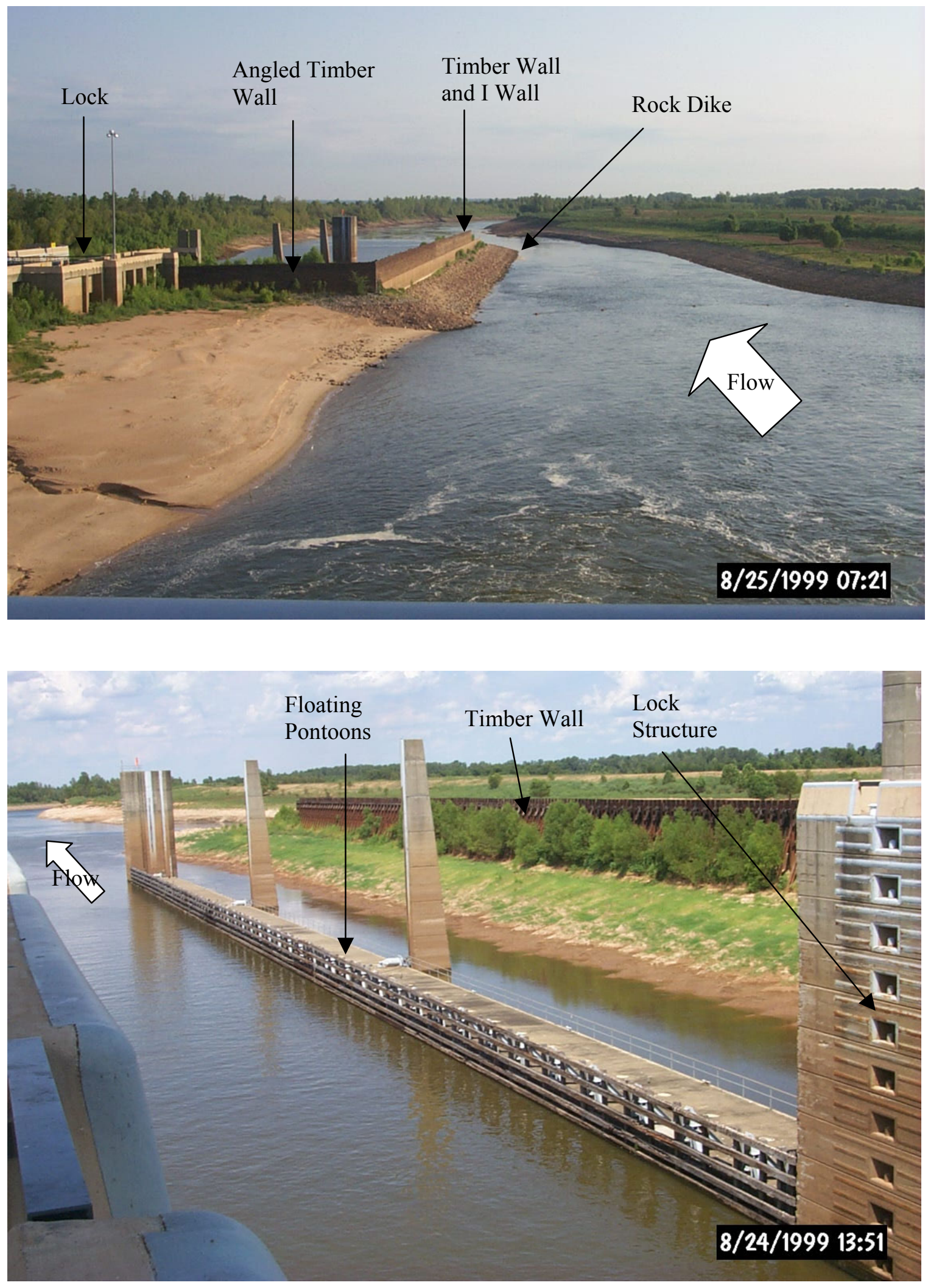

Figure 2. Annotated photographs of existing site 
Dredging has been required on an annual or semi-annual basis to remove sediment from beneath the floating guide wall. The barrier has reduced the amount of sediment deposited in the lower lock approach. However, the lower floating guide wall is still removed yearly or semi-annually for sediment removal from beneath the lower pontoons. Pontoon removal has resulted in minor damage to the pontoons. With the guide wall removed, damage can occur from barge impacts on the end of the lock approach wall adjacent to the location of the guide wall. 


\section{Design-Improvement Alternatives for the Lower Lock Approach}

\subsection{Description of Alternatives}

Michael Baker, Inc., conducted a lower lock approach sediment control study consisting of six alternatives for solving the sedimentation problem. This study involved performing preliminary engineering design on each of the six alternatives and obtaining costs and benefits with associated uncertainties and risks. Of the six alternatives, the Corps considered two viable and worthy of further investigation. The two viable alternatives were expanded into three alternatives for further investigation and preliminary design. Neel-Schaffer, Inc., examined the three alternatives and performed design analyses on each alternative proposing to solve or reduce the sedimentation. Three alternatives were assessed, based on costs and benefits with associated uncertainties and risks, to select the best design improvement.

The proposed alternatives to the sedimentation problem are listed below.

a. Remove the timber barrier, concrete I-wall, and dike and build a fixed guide wall.

b. Remove the timber barrier and the concrete I-wall and build a fixed guide wall.

c. Extend the existing timber barrier downstream an additional $400 \mathrm{ft}$ $(122 \mathrm{~m})$, replace the timber wall with concrete panels, and encase the steel H-pile support frames in concrete.

\subsubsection{Alternative A: New Fixed Guide Wall with Dike Removal}

The existing floating guide wall pontoons will be removed and disposed of, and a new cast-in-place guide wall will be constructed. The foundation and the lower part of this fixed guide wall will consist of a sheet-pile cell and pilesupported cast-in-place concrete footing. The new guide wall will be constructed to the same elevation as that of the lock walls and to the same length as the existing floating guide wall. The existing timber curtain walls, concrete I-wall, 
earthen dike, and a portion of the T-wall will be removed and disposed of. The backfill on the riverside of the guide wall will match the slope of the lock wall backfill and will taper to no backfill at the downstream end of the guide wall. A new dock dike extending $400 \mathrm{ft}(122 \mathrm{~m})$ downstream from the new fixed guide wall shall be constructed. All excess material from the dike will be relocated to the left descending bank of the downstream lock approach channel to construct a navigation channel width of $115 \mathrm{ft}(35 \mathrm{~m})$, measured from the guide wall to the toe of the left descending bank. This width is consistent with the width at Richard B. Russell Lock and Dam (formerly Lock and Dam No. 4) on the J. Bennett Johnston Waterway.

\subsubsection{Alternative B: New Fixed Guide Wall with Retention of Dike}

The existing floating guide wall pontoons will be removed and disposed of, and a new cast-in-place guide wall will be constructed. The foundation and the lower part of this fixed guide wall will consist of a sheet-pile cell and pilesupported cast-in-place concrete footing. The new guide wall will be constructed to the same elevation as that of the lock walls and to the same length as the existing floating guide wall. The existing timber curtain walls, concrete I-wall, and a portion of the T-wall will be removed and disposed of. The existing dike will remain in place. The backfill on the riverside of the guide wall will match the top elevation of the existing dike until the end of the guide wall is reached, where the backfill between the existing dike and the guide wall will taper to no backfill at the downstream end of the guide wall. The left descending bank of the downstream lock approach channel will be filled in with suitable material to construct a navigation channel width of $115 \mathrm{ft}(35 \mathrm{~m})$, measured from the guide wall to the toe of the left descending bank. This width is consistent with the width at Russell B. Long Lock and Dam.

\subsubsection{Alternative C: Barrier Extension and Use of Concrete Panels}

The timber barrier wall (including the angled timber wall) will be removed, disposed of, and replaced with solid precast concrete wall panels. This alternative will require constructing a new T-wall along the limits of the existing angled wall. New structural steel framing members will be used to attach the new concrete panels to the existing steel H-pile A-frame structure. The new concrete panels will be built to the same elevation as that of the existing timber walls (el 55.0) and will be extended to the end of the existing I-wall (sta 20+15L). A new section, including new concrete wall panels and supporting H-pile A-frame structures, will be constructed approximately $200 \mathrm{ft}(61 \mathrm{~m})$ farther downstream to sta $22+16.65 \mathrm{~L}$. The dike will also be built up to el 24.25 for approximately $200 \mathrm{ft}$ downstream. The steel H-piles will be cleaned of any foreign materials (existing piles only), repaired as necessary (existing piles only), and concrete encased. Other items of work to be completed in this alternative include excavating the downstream lock approach channel to el -7.0 and excavating the silt on the dike to its original as-built shape and condition.

\subsection{Assessment of the Alternatives}

Over the past 4 years, an average of approximately $310,000 \mathrm{cu}$ yd $(237,000 \mathrm{cu} \mathrm{m})$ of silt has been removed annually from the lower lock approach 
channel at Lindy Claiborne Boggs Lock and Dam. The proposed improvements to control this sedimentation defined in the three alternatives above include the removal of the timber curtain walls and concrete I-wall and the construction of a new sheet-pile cell/cast-in-place concrete guide wall to serve as a sediment barrier. Neel-Schaffer, Inc., assessed these alternatives as summarized below.

\subsubsection{Alternative A: New Fixed Guide Wall with Dike Removal}

Removing the dike would allow water passing through the dam gates to more nearly flow in a straight line, thereby reducing the crosscurrents that help carry sediment into the lock approach channel. Based upon dredging results at other installations that employ a guide wall system similar to the proposed system, annual dredging requirements would be approximately $50,000 \mathrm{cu}$ yd $(38,000 \mathrm{cu} \mathrm{m})$. This accumulation of sediment could be maintained by maintenance dredging and would not impede barge traffic.

The construction phase of the proposed improvements using the sheet-pile cell foundation would be simplified in that dewatering would not be necessary. The lock approach channel would likely be encroached to some extent during construction but would be kept to an acceptable encroachment of $42 \mathrm{ft}(13 \mathrm{~m})$ or half the width of the lock. All excess material from the dike would be relocated to the left descending bank of the downstream lock approach channel. A navigation channel width of $115 \mathrm{ft}(35 \mathrm{~m})$ would be maintained through the downstream lock approach, measured from the guide wall to the toe of the left descending bank.

The total cost of the proposed improvements needs to be estimated, but is not yet available. Also, the construction cost and the present worth of dredging cost need to be estimated. The proposed improvements are assumed to incur no maintenance costs over the 50-year service life of the lock and dam, except for the periodic inspection costs incurred every 5 years. The construction cost should include the removal and disposal of the existing timber walls, concrete T-wall, and floating pontoons.

\subsubsection{Alternative B: New Fixed Guide Wall with Retention of Dike}

By allowing the dike to remain at el 24.25 to provide a low-water sedimentation barrier and constructing the fixed guide wall, annual dredging requirements are estimated to be approximately $50,000 \mathrm{cu}$ yd $(38,000 \mathrm{cu} \mathrm{m})$. This accumulation of sediment could be maintained by maintenance dredging and would not impede barge traffic.

The construction phase of the proposed improvements using the sheet-pile cell foundation would be simplified in that dewatering would not be necessary. The lock approach channel would likely be encroached to some extent during construction but would be kept to an acceptable encroachment of $42 \mathrm{ft}(13 \mathrm{~m})$ or half the width of the lock. A navigation channel width of $240 \mathrm{ft}(73 \mathrm{~m})$ would be maintained through the downstream lock approach, measured from the guide wall to the toe of the left descending bank. 
The total cost of the proposed improvements needs to be estimated but is not yet available. Also, the construction cost and the present worth of dredging cost need to be estimated. The proposed improvements are assumed to incur no maintenance costs over the 50-year service life of the lock and dam, except for the periodic inspection costs incurred every 5 years. The construction cost should include the removal and disposal of the existing timber walls, concrete T-wall, and floating pontoons.

\subsubsection{Alternative C: Barrier Extension and Use of Concrete Panels}

This alternative controls the sedimentation by replacing the existing timber walls with precast concrete panels and a $400-\mathrm{ft}(122-\mathrm{m})$ extension of the wall. By extending the wall $400 \mathrm{ft}(122 \mathrm{~m})$ downstream and replacing the existing timber walls with precast panels, annual dredging requirements would be reduced to $50,000 \mathrm{cu}$ yd $(38,000 \mathrm{cu} \mathrm{m})$.

The proposed improvements could be constructed without hindering traffic through the lock in any way.

The total cost of the proposed improvements needs to be estimated but is not yet available. Also, the construction cost and the present worth of dredging cost need to be estimated. The assumed future maintenance items associated with the approach improvements include the removal of the pontoons every 3 years, the replacement of the timber fenders of the floating guide wall every 5 years, and repainting all metal structures every 17 years. 


\section{Objective and Scope}

The U.S. Army Engineer District, Vicksburg, requires the probability of catastrophic failure during the construction and utilization phases of the lockimprovement alternatives, including potential catastrophic damage occurring to the floating guide wall pontoons while they are being removed, transported to and from their temporary storage area, and reinstalled. Catastrophic damage is defined as one of the following:

a. The sinking or destruction of any one or all of the pontoons.

$b$. Sufficient damage occurring to any pontoon to require repair or replacement.

The probability of this type damage occurring within the navigation channel or the lock chamber, thus shutting down the waterway to barge traffic until the sunken or destroyed pontoon can be removed from the navigation channel, is also required.

The needs of the District can be met by performing probabilistic risk assessment and management to identify initiating events and failure scenarios, and to assess their occurrence probabilities and consequences. The results should be expressed in a manner suitable for total life-cycle cost analysis and the use of decision-makers.

The methodology used in this analysis (described in the succeeding chapter) covers key aspects of the Preliminary Hazard Analysis process. The proposed risk-based methodology begins with system definition and progresses to definition of work tasks for the three alternatives. The tasks in every phase of each alternative are assessed for risk, examining associated initiating events, failure scenarios, consequences, and occurrence probability. Initiating events and failure scenarios are identified and enumerated. Consequences and occurrence probability are determined by subjective evaluations in linguistic terms using linguistic variables. The methodology includes development of risk profiles and decision analysis. 


\section{Methodology}

\subsection{Components}

The proposed risk-based methodology includes the following components:

a. System definition.

b. Definition of work tasks for the three alternatives.

c. For each alternative, each phase and each task, assessment of the initiating events, failure scenarios using event and fault trees as needed, basic events and their occurrence probabilities, occurrence probabilities of failure scenarios, consequences of failure scenarios, total present value of failure consequences for a typical life cycle, construction duration and cost information for alternatives, and total present value of construction cost.

d. Development of risk profiles and performance of decision analysis.

These components are described in detail in the work breakdown structure presented below. The work breakdown structure shows the hierarchy of tasks for each alternative.

\subsection{Definition and Architecture (Primary Logic Boxes)}

- System definition

o Identification of phases (three)

- Construction phase

- Utilization phase (utilization life $=50$ years)

- Disposal phase (not included in the study)

o Definition of decision alternatives

- Alternative A: New fixed guide wall with dike removal

- Alternative B: New fixed guide wall with retention of dike

- Alternative C: Barrier extension and use of concrete panels

o Definition and collection of data 
- Definition of work tasks for each alternative

o Alternative A: New fixed guide wall with dike removal

- Definition of primary construction-phase tasks

$\checkmark$ Remove and dispose of existing pontoons

o

Removal of lower floating guide wall pontoons

$\checkmark$ Requires a work crew of approximately eight people

- Shut lock chamber to all lockages for approximately 4 to $6 \mathrm{hr}$

- Use two skiffs and one mule barge and/or towboat to move pontoons from their position in the guide wall and into lock chamber

- Remove and secure all three sections (pontoons) in chamber after they are taken loose from guide beams. Remove in the order pontoon 3, then 2, and finally 1 . Pontoon 3 is farthest downstream. This process takes approximately 3 to $4 \mathrm{hr}$. Once this process has begun, the work cannot be stopped until all three pontoons are disconnected, moved, and secured in the chamber.

- Remove the pontoons from the chamber and float them to the upstream guide wall location and secure off. This process requires approximately 3 to $4 \mathrm{hr}$ if weather conditions are favorable. High winds can hamper this operation.

$\checkmark$ Construct the sheet-pile cells and pile-supported footing for the new guide wall

$\checkmark$ Construct the new cast-in-place guide wall (above el 16.5)

$\checkmark$ Construct the new cast-in-place guide wall (lower than el 16.5)

$\checkmark$ Remove and dispose of timber curtain wall

$\checkmark$ Remove and dispose of the concrete I-wall and sheet pile

$\checkmark$ Remove and dispose of portion of the concrete T-wall

$\checkmark$ Remove the earth dike downstream from the new guide wall

$\checkmark$ Backfill and riprap behind the guide wall

$\checkmark$ Relocate excess materials from the dike to the landside bank of the downstream lock approach channel

$\checkmark \quad$ Maintain barge traffic during construction (42-ft (13-m) width)

- Definition of scheduled utilization-phase tasks

$\checkmark$ Provide annual dredging of 50,000 cu yd (38,000 cu m)

$\checkmark$ Maintain traffic during dredging

$\checkmark$ Provide any needed inspection, maintenance, and repair

Inspections held every year for first 5 years, then once every 5 years thereafter

o Alternative B: New fixed guide wall with retention of dike

- Definition of primary construction-phase tasks

$\checkmark$ Remove and dispose of existing pontoons

o Removal of lower floating guide wall pontoons

- Requires a work crew of approximately eight people

- Shut lock chamber to all lockages for approximately 4 to $6 \mathrm{hr}$

- Use two skiffs and one mule barge and/or towboat to move pontoons out of the location and into lock chamber

- Remove and secure all three sections (pontoons) in chamber after they are taken loose from guide beams. Remove in the order pontoon 3, then 2, and finally 1 . Pontoon 3 is farthest downstream. This process takes approximately 3 to $4 \mathrm{hr}$. Once this process has begun, work cannot be stopped until all three pontoons are disconnected, moved, and secured in the chamber. 
- Remove the pontoons from the chamber and float them to the upstream guide wall location and secure off. This process requires approximately 3 to $4 \mathrm{hr}$ if weather conditions are favorable. High winds hamper this operation.

$\checkmark$ Construct the sheet-pile cells and pile-supported footing for the new guide wall

$\checkmark$ Construct the new cast-in-place guide wall (above el 16.5)

$\checkmark$ Construct the new cast-in-place guide wall (lower than el 16.5)

$\checkmark$ Remove and dispose of timber curtain walls

$\checkmark$ Remove and dispose of the concrete I-wall

$\checkmark$ Remove and dispose of portion of the T-wall

$\checkmark$ Backfill and riprap behind the guide wall

$\checkmark \quad$ Maintain barge traffic during construction (42-ft width)

- Definition of Scheduled Utilization-Phase Tasks

$\checkmark$ Provide annual dredging of $38,000 \mathrm{cu} \mathrm{m}(50,000 \mathrm{cu} \mathrm{yd})$

$\checkmark$ Maintain traffic during dredging

$\checkmark \quad$ Provide any needed inspection, maintenance and repair

Inspections held every year for first 5 years, then once every 5 years thereafter.

o Alternative C: Barrier extension and use of concrete panels

- Definition of primary construction-phase tasks

$\checkmark$ Construct new concrete panels

$\checkmark$ Excavate the silt on the dike to its original as-built condition

$\checkmark$ Clean up and repair existing H-piles and encase in concrete

$\checkmark$ Construct new structural steel A-frame and encase in concrete for a distance of $400 \mathrm{ft}(122 \mathrm{~m})$ downstream from existing Aframes

$\checkmark$ Remove and dispose of timber wall

$\checkmark$ Attach the new solid precast concrete panels to the existing and new structural steel frames

$\checkmark$ Maintain barge traffic during construction (84-ft (26-m) width)

- Definition of scheduled utilization-phase tasks

$\checkmark$ Provide annual dredging of 50,000 cu yd $(38,000 \mathrm{cu} \mathrm{m})$

$\checkmark$ Maintain traffic during dredging

$\checkmark$ Remove the pontoons once every 3 years for dredging, dredge and reposition the pontoons

o Removal of lower floating guide wall pontoons

- Requires a work crew of approximately eight people

- Shut lock chamber to all lockages for approximately 4 to $6 \mathrm{hr}$

- Use two skiffs and one mule barge and/or towboat to move pontoons out of the location and into lock chamber

- Remove and secure all three sections (pontoons) in chamber after they are taken loose from guide beams. Remove in the order pontoon 3, then 2, and finally 1. Pontoon 3 is farthest downstream. This process takes approximately 3 to $4 \mathrm{hr}$. Once this process has begun, work cannot be stopped until all three pontoons are disconnected, moved, and secured in the chamber.

- Remove the pontoons from the chamber and float them to the upstream guide wall location and secure off. This process requires approximately 3 to $4 \mathrm{hr}$ if weather conditions are favorable. High winds can hamper this operation. 
o Storage of downstream floating guide wall behind upstream floating guide wall

- Approximately once a week, pontoons are inspected for loose ropes or lines and to ensure that they are not in contact with any other concrete surfaces. Rubber tires are placed between each section (pontoon) to keep the sections from touching any other concrete surfaces.

- Pontoons may be out and secured behind upstream guide wall anywhere from 3 to 6 months depending on downstream river elevation.

o Reinstallation of downstream floating guide wall

- Requires a towboat and two skiffs

- Same crew size needed as required to remove pontoons.

- Pontoons are floated out of their stored location and into lock chamber. They are secured off in opposite order they are to be installed, with pontoon 1 being next to lock. This requires approximately 3 to $4 \mathrm{hr}$, during which the lock chamber is shut down to traffic.

- Remove from chamber and push into place one pontoon at a time. Attach pontoon to guide beams-pontoon 1 first, then 2, and finally 3 . Chamber still shut down. This requires approximately 4 to $6 \mathrm{hr}$.

$\checkmark$ Replace the timber fenders of the floating guide wall every 5 years

o Replacing timbers on guide wall

- This operation was done on the upstream guide wall and required a crew of approximately 4 to 6 men with a towboat and work barge, over a period of 60 to 90 days. No traffic is delayed, and lock is never shut down. Work barge is moved on and off location when needed.

o Disposal of old timbers

- All of the existing timbers are creosoted pine. These old timbers have to be placed on the bank and trucked to a certified state landfill for disposal. This requires numerous truckloads to accomplish.

$\checkmark$ Provide any needed inspection, maintenance, and repair

o Inspections held every year for first 5 years, then once every 5 years thereafter

$\checkmark \quad$ Paint all structural steel every 17 years

- For each alternative, each phase, and each task, the following items need to be assessed:

o Initiating events

o Failure scenarios using event trees

o Fault trees for underlying events in the event trees

o Basic events and their occurrence probabilities

o Occurrence probabilities of failure scenarios

o Consequences of failure scenarios

o Total present value of failure consequences for a typical life cycle

o Construction duration and cost information for alternatives

o Total present value of construction cost

- Development of risk profiles and decision analysis 
The life-cycle cost consists of the costs during the construction phase (including failure cost) and the costs during the utilization phase (including inspection, maintenance, repair, and failure cost). The results from the methodology can be used in a decision tree as shown in Figure 3.

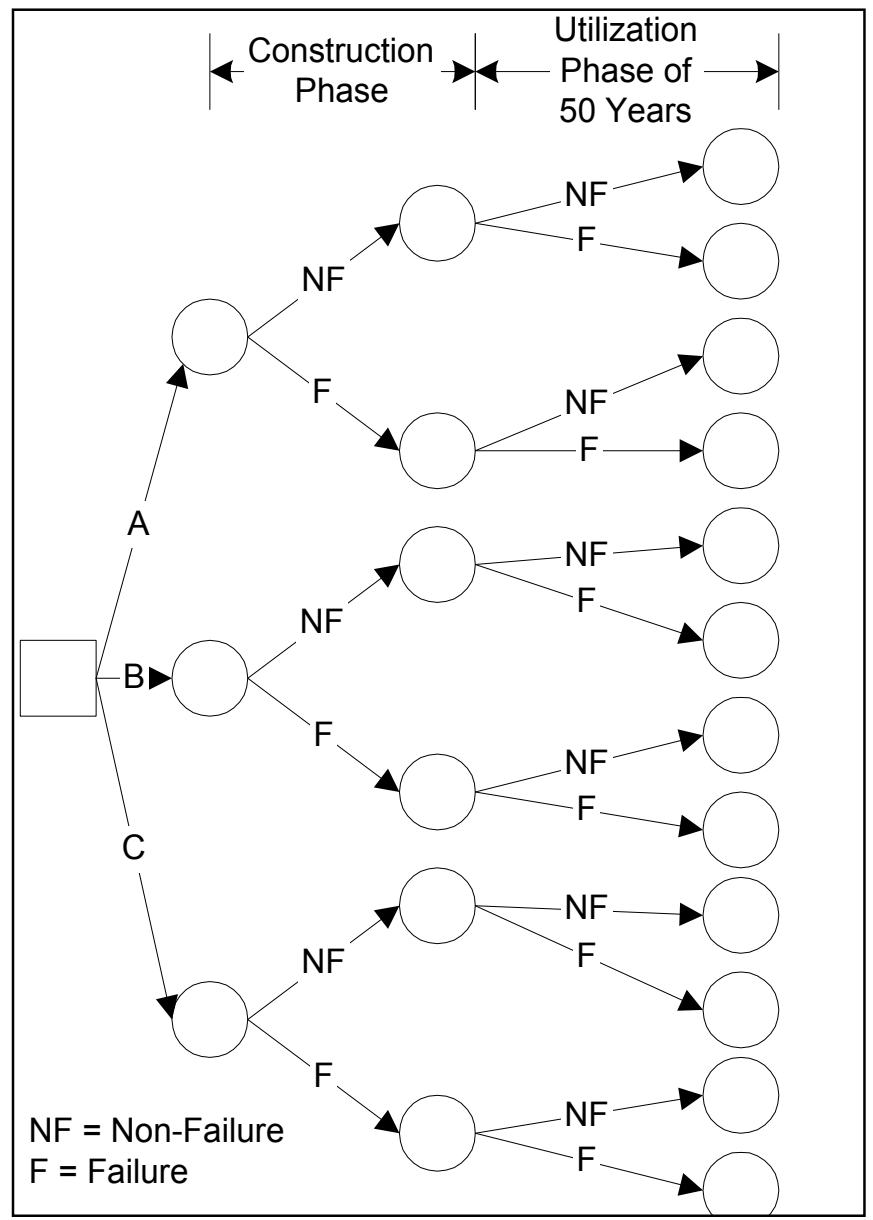

Figure 3. Decision tree 


\section{Data Needs and Collection}

The proposed methodology requires data and information of failure probabilities and consequences for the various tasks of the three alternatives. Such information and data are not available from empirical sources, and need to be assessed subjectively using expert-opinion elicitation.

Expert-opinion elicitation can be defined as a heuristic process of gathering information and data or answering questions on issues or problems of concern. In this study, the focus is on occurrence probabilities and consequences of events related to the construction and utilization phases to facilitate comparison of the three alternatives. For this purpose, the expert-opinion elicitation process can be defined as a formal process of obtaining information or answers to specific questions about certain quantities, called issues, such as failure probabilities and consequences. The suggested expert-opinion elicitation process is a variation of the Delphi technique (Helmer 1968) scenario analysis (Kahn and Wiener 1967) based on uncertainty models (Ayyub 1992, 1999a, b; Cooke 1991); social research (Bailey 1994); U.S. Army Corps of Engineers studies (Ayyub, Riley, and Hoge 1996; Baecher 1998); ignorance, knowledge, information and uncertainty, experts and opinions; nuclear industry recommendations (Nuclear Regulatory Commission 1997); and Stanford Research Institute protocol (Spetzler and Stael von Holstein 1975). A typical expert-opinion elicitation process is illustrated in Figure 4.

An expert-opinion elicitation session was conducted for this study and is reported in a separate technical report (Ayyub, Blair, and Patev 2002). 


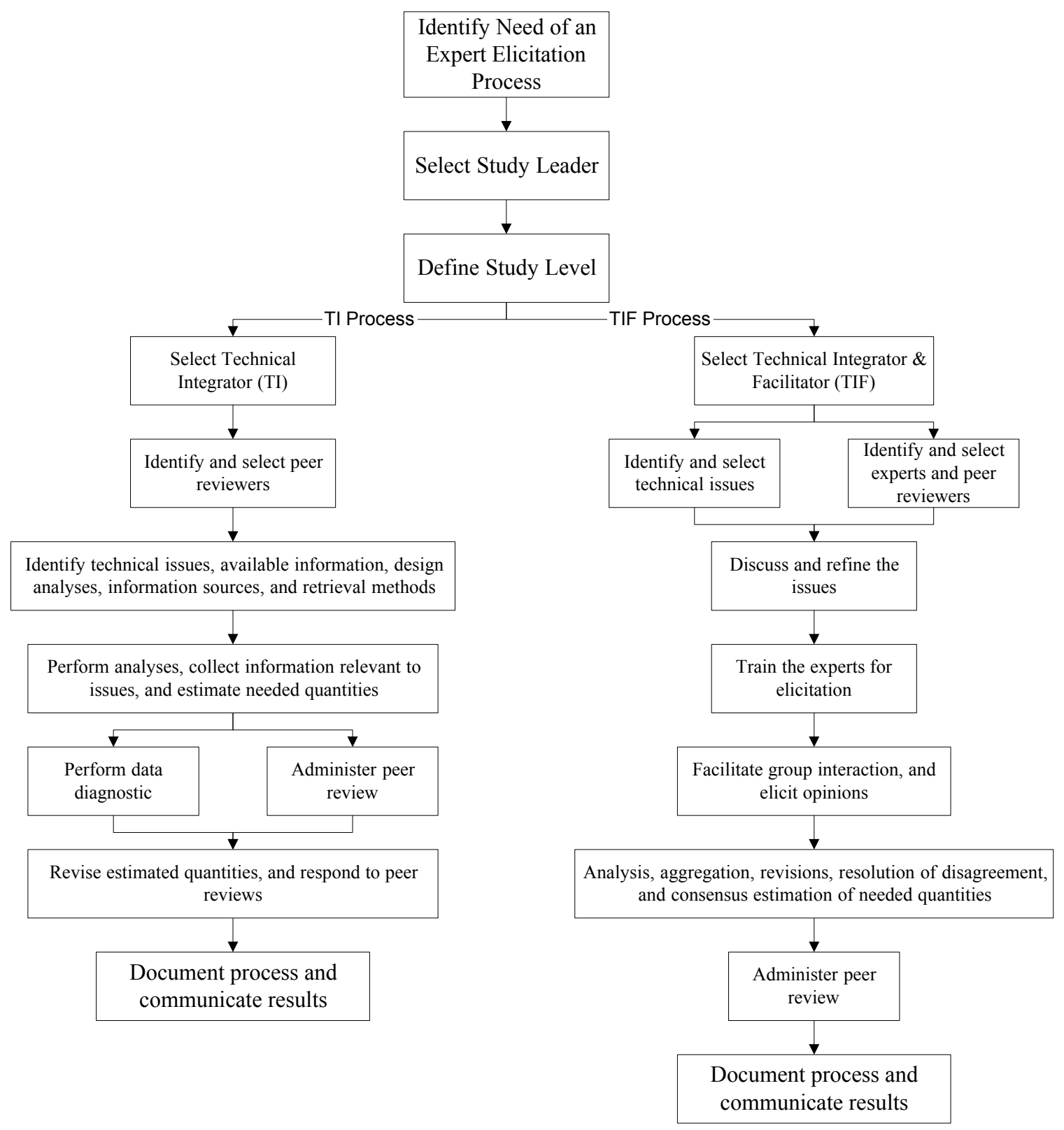

Figure 4. Expert-opinion elicitation process 


\section{Results of Risk Assessment}

Figure 5 depicts a decision tree that is used to assess the risk associated with a given initiating event of a given scenario for a given alternative. Figure 6 is an event-on-node representation of the same information. A decision tree such as Figure 5 or an event-on-node diagram such as Figure 6 is required for every initiating event of each alternative. A complete representation of all decision aspects requires over 40 such decision trees or event-on-node diagrams. This decision information is more concisely provided in the form of return matrices, one for every phase of each alternative.

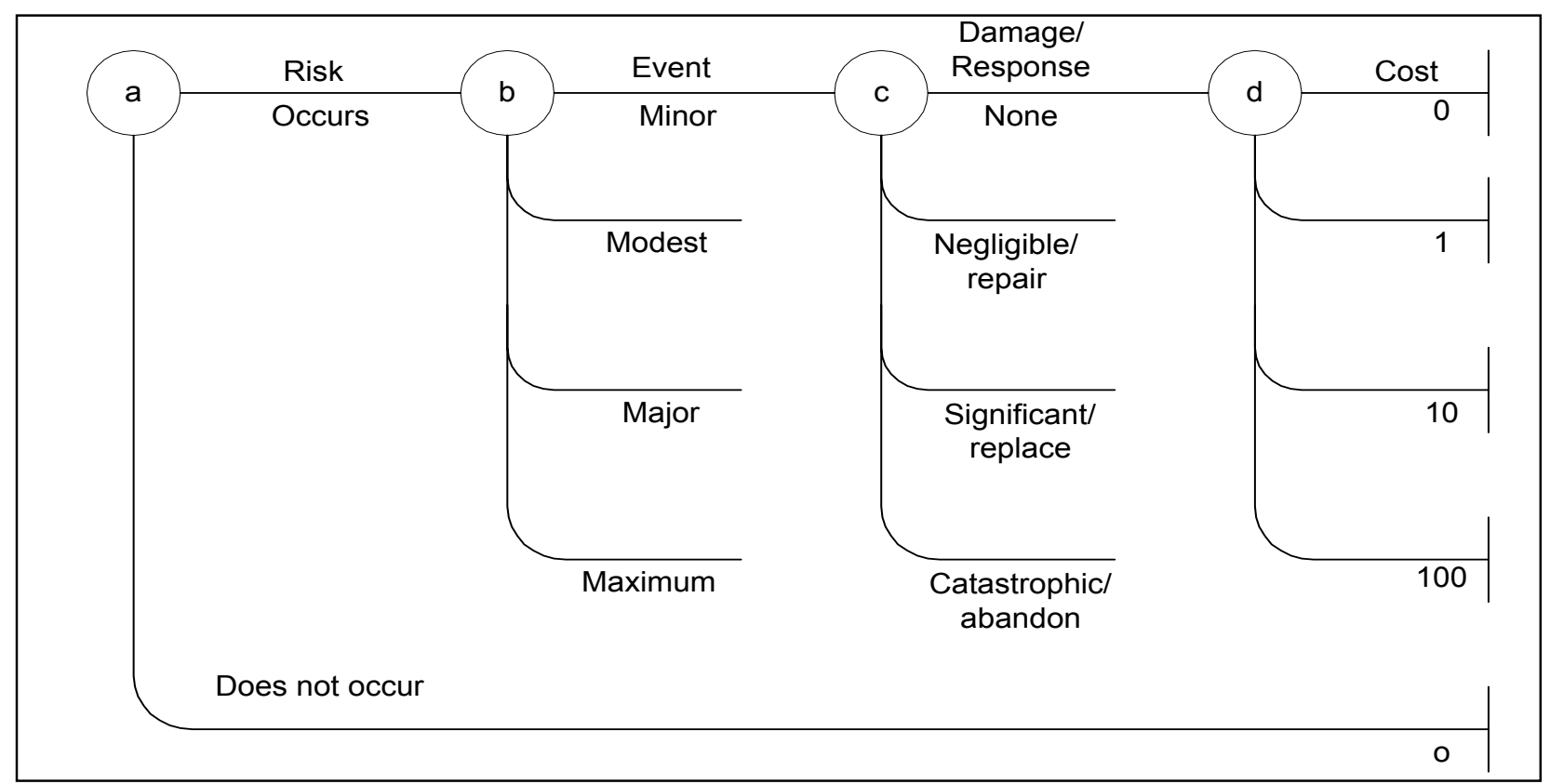

Figure 5. Decision tree for risk of one initiating event of one scenario for an alternative

\subsection{Qualitative Risk Matrices}

This method of risk assessment qualitatively describes both the likelihood of occurrence and the consequences of an adverse event. From the combination of these two terms, a quantitative risk assessment is derived. The quantified risks for various scenarios can be used to perform comparisons among scenarios. The 


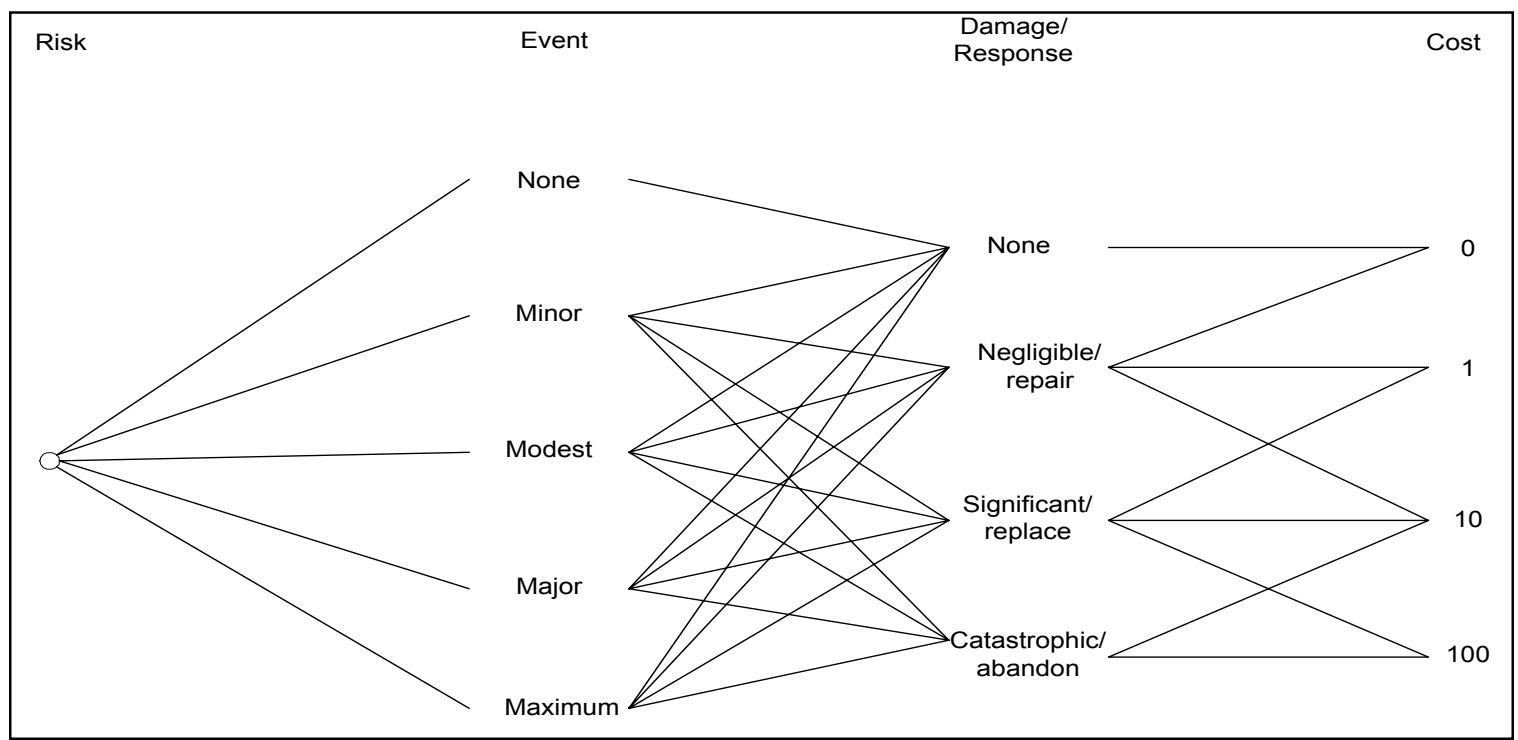

Figure 6. Event-on-node form of risk of one initiating event of one scenario for an alternative

National Aeronautics and Space Administration has used risk assessment matrices to avoid the problem of managers treating the values of probability and risk as absolute judgments (Wiggins 1985). The Department of Defense offers the use of risk assessment matrices as a tool to prioritize risk (Defense Acquisition University 1998). The tasks in every phase of each alternative are assessed for risk, examining associated initiating events, failure scenarios, consequences, and occurrence probability. Initiating events and failure scenarios are identified and enumerated. Consequences and occurrence probability can be determined by subjective evaluations. These subjective evaluations can be in linguistic terms using linguistic variables whose values are natural language expressions referring to the quality of interest.

The values of the linguistic variable Consequence include very low, low, medium, high, and very high. The costs resulting from these consequences can be approximated by the values given in Table 1 .

The values of the linguistic variable Occurrence Probability include very low, low, moderate, high, and very high likelihood. The probabilities resulting from these likelihoods can be approximated by the values given in Table 2 .

A number of tasks and initiating events for each alternative and phase are conventional construction activities with related and similar conventional construction risk. In assessing risks for each alternative and phase, these activities are placed in an initiating event category "Conventional Construction," and the failure scenarios, consequences, and occurrence probability are assessed for the category as a whole.

Risks are then prioritized and categorized by pairing likelihood and consequence, as shown in Table 3. This risk assessment matrix is particularly suitable in this case because of the reliance on "semiquantitative" data and the uniqueness of the project for which specific data may not be available. 


\section{Table 1 \\ Cost Approximation of Consequence Linguistic Variable (Present Value)}

\begin{tabular}{||l|l|}
\hline Consequence Linguistic Variable & Cost Approximation \\
\hline \hline Very low & Less than $\$ 50,000$ \\
\hline Low & $\$ 100,000$ \\
\hline Medium & $\$ 500,000$ \\
\hline High & $\$ 1$ million \\
\hline Very high & Over $\$ 10$ million \\
\hline
\end{tabular}

\section{Table 2}

Probability Approximation of Likelihood Linguistic Variable

\begin{tabular}{||l|l||}
\hline \hline Likelihood Linguistic Variable & Probability Approximation \\
\hline \hline Very low & $10^{-3}$ \\
\hline Low & $2.5 \times 10^{-2}$ \\
\hline Medium & $5 \times 10^{-2}$ \\
\hline High & $7.5 \times 10^{-2}$ \\
\hline Very high & 0.1 \\
\hline
\end{tabular}

\section{Table 3}

\section{Risk Assessment Matrix}

\begin{tabular}{||l|l|l|l|l|l||}
\hline \multirow{2}{*}{$\begin{array}{l}\text { Likelihood } \\
\text { Level }\end{array}$} & \multicolumn{5}{|c||}{ Consequence Level } \\
\cline { 2 - 6 } & Very low & Low & Medium & High & Very high \\
\hline \hline Very low & Low & Low & Low & Low & Moderate \\
\hline Low & Low & Low & Low & Moderate & High \\
\hline Medium & Low & Low & Moderate & High & High \\
\hline High & Low & Moderate & Moderate & High & High \\
\hline Very high & Low & Moderate & High & High & High \\
\hline
\end{tabular}

\subsection{Expert-Opinion Elicitation}

Information related to failure probability and consequences is not available from historical records, prediction methods, or literature review. Expert-opinion elicitation provides a means of gaining information on these essential risk-related quantities. The expert-opinion elicitation process is a formal, heuristic process of obtaining information or answers to specific questions about certain quantities, called issues, such as failure rates (probability) and failure consequences. Ayyub, Blair, and Patev (2002) document the expert-opinion elicitation performed to 
meet risk analysis needs of the design-improvement alternatives to the Lindy C. Boggs Lock and Dam. In the report (Ayyub, Blair, and Patev 2002), the different components of the expert-opinion elicitation process are described, the process is outlined, and the results are documented. The results of expert-opinion elicitation are documented in the form of an Expert-Opinion Elicitation and Results Matrix for every issue, initiating event, and scenario.

\subsection{Risk Assessment of Alternative A}

The return matrices for the risk assessment of Alternative A are given in Tables 4 and 5. Consequences and likelihood estimates in Tables 4 and 5 are obtained from the expert elicitation documented in Ayyub, Blair, and Patev (2002). Supportive reasoning and assumptions made by the experts, as well as the level of confidence of the experts in their assessments, are reported in Ayyub, Blair, and Patev (2002). The product of the cost and probability estimates obtained by expert-opinion elicitation is the expected value of the cost of risk of each scenario. The sum of expected values of the cost of risk of all scenarios in each phase gives a profile of costs due to risk for Alternative A with an initial construction risk cost of $\$ 1,403,140$ and a recurring annual risk cost of $\$ 8,500$.

\begin{tabular}{|c|c|c|c|}
\hline Alternative & Initiating Event & $\begin{array}{l}\text { Risk Assessment } \\
\text { Expected Value } \\
\end{array}$ & Total \\
\hline A & $\begin{array}{l}\text { Remove pontoons } \\
\text { Remove I-wall and sheet pile } \\
\text { Remove T-wall } \\
\text { Remove timber curtain wall } \\
\text { Attach timber curtain wall } \\
\text { Conventional construction: } \\
\text {-Construction of guidewalls (above } 16.5 \mathrm{ft} \text { ) } \\
\text {-Construction of guidewalls base (lower than el } 16.5 \mathrm{ft} \text { ) } \\
\text {-Construction of concrete panels } \\
\text {-Removal of earth dike } \\
\text {-Backfill and riprap } \\
\text {-Relocation of excess material } \\
\text {-Excavation of silt } \\
\text { Maintain traffic }\end{array}$ & $\begin{array}{r}\$ 103.95 \\
86.56 \\
60.00 \\
65.00 \\
54.63 \\
\\
20.00 \\
33.00 \\
0.00 \\
7.50 \\
7.50 \\
7.50 \\
7.50 \\
950.00\end{array}$ & $\$ 1,403.14$ \\
\hline
\end{tabular}

Table 5

Return Matrix for Utilization Phase of Alternative A (thousands of dollars)

\begin{tabular}{||l|l|l|l||}
\hline \hline Alternative & Initiating Event & $\begin{array}{l}\text { Risk Assessment } \\
\text { Expected Value }\end{array}$ & Total \\
\hline \hline A & Annual dredging & $\$ 8.50$ & $\$ 8.50$ \\
\hline & Inspection maintenance and repair & 0.00 & \\
\hline
\end{tabular}




\subsection{Risk Assessment of Alternative B}

The return matrices for the risk assessment of Alternative B are given in Tables 6 and 7. Consequences and likelihood estimates in Tables 6 and 7 are obtained from the expert elicitation documented in Ayyub, Blair, and Patev (2002). Supportive reasoning and assumptions made by the experts, as well as the level of confidence of the experts in their assessments, are reported in Ayyub, Blair, and Patev (2002). The product of the cost and probability estimates obtained by expert-opinion elicitation constitutes the expected value of the cost of risk of each scenario. The sum of expected values of the cost of risk of all scenarios in each phase gives a profile of costs due to risk for Alternative B with an initial construction risk cost of $\$ 1,388,140$ and a recurring annual risk cost of $\$ 8,500$.

\begin{tabular}{|c|c|c|c|}
\hline \multicolumn{4}{|c|}{$\begin{array}{l}\text { Table } 6 \\
\text { Return Matrix for Construction Phase of Alternative B (thousands of dollars) }\end{array}$} \\
\hline Alternative & Initiating Event & $\begin{array}{l}\text { Risk Assessment } \\
\text { Expected Value } \\
\end{array}$ & Total \\
\hline B & $\begin{array}{l}\text { Remove pontoons } \\
\text { Remove I-wall and sheet pile } \\
\text { Remove T-wall } \\
\text { Remove timber curtain wall } \\
\text { Attach timber curtain wall } \\
\text { Conventional construction: } \\
\text {-Construction of guidewalls (above } 16.5 \mathrm{ft} \text { ) } \\
\text {-Construction of guidewalls base (lower than el } 16.5 \mathrm{ft} \text { ) } \\
\text {-Construction of concrete panels } \\
\text {-Backfill and riprap } \\
\text {-Excavation of silt } \\
\text { Maintain traffic }\end{array}$ & $\begin{array}{r}\$ 103.95 \\
86.56 \\
60.00 \\
65.00 \\
54.63 \\
\\
20.00 \\
33.00 \\
0.00 \\
7.50 \\
7.50 \\
950.00\end{array}$ & $\$ 1,388.14$ \\
\hline
\end{tabular}

\begin{tabular}{|c|c|c|c|}
\hline Alternative & Initiating Event & $\begin{array}{l}\text { Risk Assessment } \\
\text { Expected Value }\end{array}$ & Total \\
\hline \multirow[t]{2}{*}{ B } & Annual dredging & $\$ 8.50$ & $\$ 8.50$ \\
\hline & Inspection maintenance and repair & 0.00 & \\
\hline
\end{tabular}

\subsection{Risk Assessment of Alternative C}

The return matrices for the risk assessment of Alternative $\mathrm{C}$ are given in Tables 8 and 9. Consequences and likelihood estimates in Tables 4 and 5 are obtained from the expert elicitation documented in Ayyub, Blair, and Patev (2002). Supportive reasoning and assumptions made by the experts, as well as the level of confidence of the experts in their assessments, are reported in Ayyub, Blair, and Patev (2002). The product of the cost and probability estimates obtained by expert-opinion elicitation constitutes the expected value of the cost of risk of each scenario. The sum of expected values of the cost of risk of all 
scenarios in each phase gives a profile of costs due to risk for Alternative $\mathrm{C}$ with an initial construction risk cost of $\$ 1,220,000$ and a recurring annual risk cost of approximately $\$ 254,020$.

The amount of recurring annual risk cost fluctuates from year to year due to assumed future maintenance needs. The assumed future maintenance needs associated with Alternative $\mathrm{C}$ that vary include the removal and reinstallation of the pontoons every 3 years, replacement of the timber fenders of the floating guide wall every 5 years, and repainting all metal structures every 17 years.

\begin{tabular}{|c|c|c|c|}
\hline Alternative & Initiating Event & $\begin{array}{l}\text { Risk Assessment } \\
\text { Expected Value }\end{array}$ & Total \\
\hline C & $\begin{array}{l}\text { Remove timber curtain wall } \\
\text { Attach precast concrete panels } \\
\text { Conventional construction: } \\
\text {-Construction of concrete panels } \\
\text {-Construct new T-wall } \\
\text {-Backfill and riprap } \\
\text {-Excavation of silt } \\
\text {-Cleaning, repairing, encasing existing H-piles } \\
\text {-Driving and encasing new H-piles }\end{array}$ & $\begin{array}{r}\$ 65.00 \\
25.00 \\
\\
0.00 \\
60.00 \\
7.50 \\
950.00 \\
112.50 \\
0.00\end{array}$ & $\$ 1,220.00$ \\
\hline
\end{tabular}

\begin{tabular}{||l|l|r|r||}
\hline $\begin{array}{l}\text { Table } 9 \\
\text { Return Matrix for Utilization Phase of Alternative C (thousands of dollars) }\end{array}$ \\
\hline \hline \multirow{2}{*}{ Alternative } & Initiating Event & $\begin{array}{l}\text { Risk Assessment } \\
\text { Expected Value }\end{array}$ & Total \\
\hline \hline C & Annual dredging & 8.50 & $\$ 254.02$ \\
& Dredging every 3 years & 8.20 & \\
& Remove pontoons & 103.95 & \\
& Reinstallation of pontoons & 123.36 & \\
& Inspection maintenance and repair & 0.00 & \\
& Replace timber fenders & 10.00 & \\
& Repainting all metal structures every 17 years & 0.01 & \\
\hline
\end{tabular}

\subsection{Comparison of Alternatives}

The approximate risk profiles, as expected costs in the form of a cash flow for Alternatives A, B, and C, are depicted in Figure 7. Alternative A has an initial construction risk cost of $\$ 1,403,140$ and a recurring annual risk cost of $\$ 8,500$ for 50 years. Alternative $\mathrm{B}$ has an initial construction risk cost of $\$ 1,388,140$ and a recurring annual risk cost of $\$ 8,500$ for 50 years. Alternative $C$ has an initial construction risk cost of $\$ 1,220,000$ and a recurring annual risk cost of 
approximately $\$ 254,020$ for 50 years. The amount of recurring annual risk costs for Alternative $\mathrm{C}$ fluctuates from year to year due to assumed future maintenance needs as discussed above.

Figure 7 shows the initial construction costs due to risk and the recurring annual costs due to risk that are amortized over the 50-year life cycle to obtain the net present value as given in Table 10. The effective discount rate used in this amortization is 5 percent, assuming a nominal discount rate of 8 percent and an inflation rate of 3 percent. The net present value of risk costs over the project's life cycle, as given in Table 10, is approximately $\$ 1.5$ million for Alternatives A and $\mathrm{B}$ and approximately $\$ 3$ million for Alternative $\mathrm{C}$.

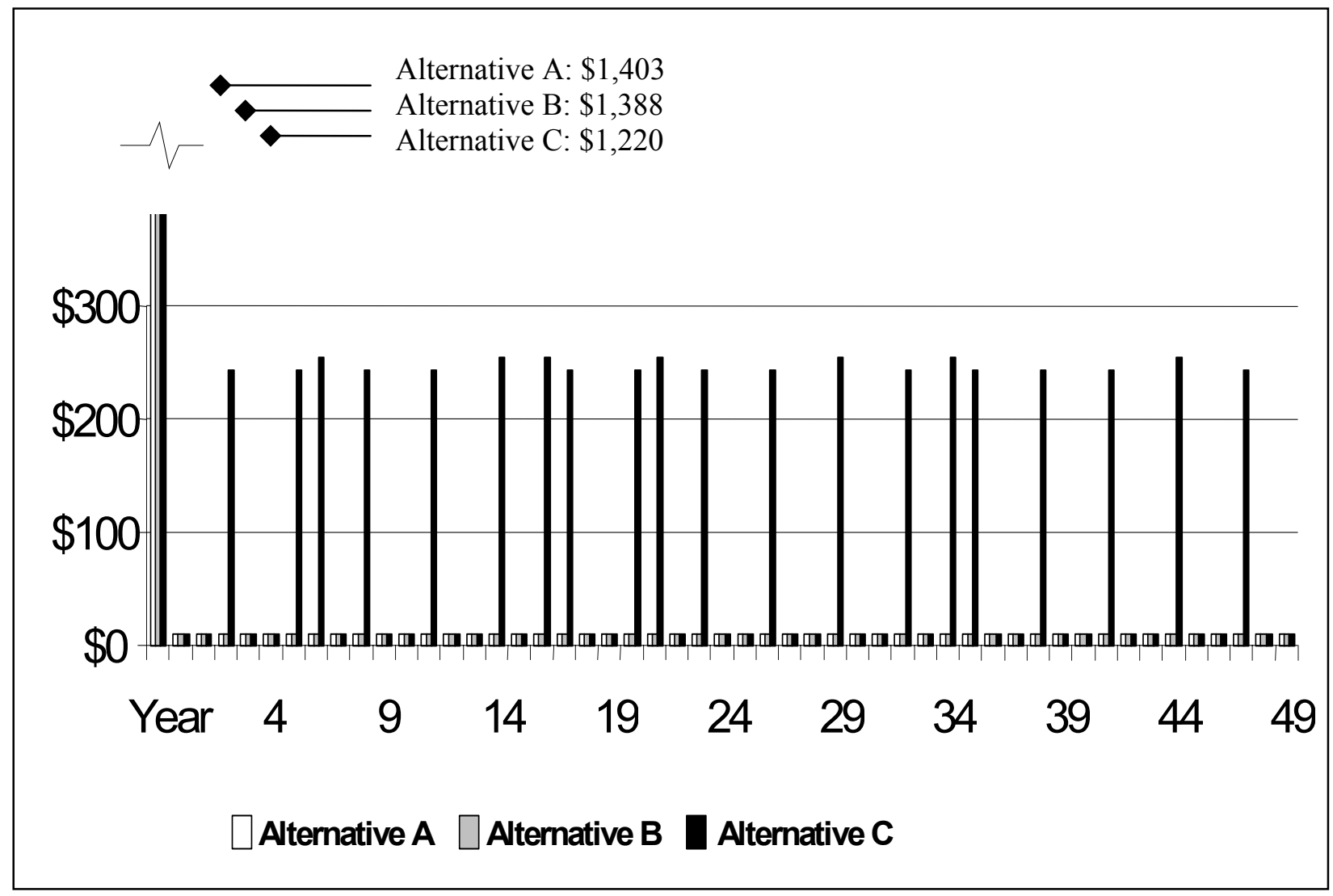

Figure 7. Risk profile for the three alternatives (thousands of dollars)

\begin{tabular}{|c|c|c|c|}
\hline \multicolumn{4}{|c|}{$\begin{array}{l}\text { Table } 10 \\
\text { Amortization of Risks Costs over Project Life Cycle (thousands } \\
\text { of dollars) }\end{array}$} \\
\hline & Alternative $\mathrm{A}$ & Alternative B & Alternative C \\
\hline Construction phase & $\$ 1,403$ & $\$ 1,388$ & $\$ 1,220$ \\
\hline Utilization phase & 9 & 9 & 254 \\
\hline Net present value & 1,484 & 1,470 & 2,994 \\
\hline
\end{tabular}




\section{Summary and Conclusions}

The Lindy C. Boggs Lock and Dam experiences variations in water-level fluctuations that are currently handled using floating guide walls upstream and downstream of the lock. A concrete T-wall is provided in anticipation of sediment deposits in the navigation channel underneath the downstream floating guide wall. A dike and I-wall are also used to divert the flow and sediment from the floating guide wall and the navigation channel. Nonetheless, an average of approximately $237,000 \mathrm{cu} \mathrm{m}(310,000 \mathrm{cu} \mathrm{yd})$ of silt has been removed annually from the lower lock approach channel at Lindy C. Boggs Lock and Dam.

The proposed solutions to the sedimentation problem are to

a. Remove the timber barrier, concrete I-wall, and dike and build a fixed guide wall.

b. Remove the timber barrier and the concrete I-wall and build a fixed guide wall.

c. Extend the existing timber barrier downstream an additional $122 \mathrm{~m}$ $(400 \mathrm{ft})$, replace the timber wall with concrete panels, and encase the steel H-pile support frames in concrete.

The methodology used in the report covers key aspects of the Preliminary Hazard Analysis process. The risk-based methodology begins with system definition, and definition of work tasks for the three alternatives. The tasks in every phase of each alternative are assessed for risk, examining associated initiating events, failure scenarios, consequences, and occurrence probability. Initiating events and failure scenarios are identified and enumerated. Information related to failure probability and consequences is not available from historical records, prediction methods, or literature review and is obtained by expertopinion elicitation (Ayyub, Blair, and Patev 2002). Supportive reasoning and assumptions made by the experts, as well as the level of confidence of the experts in their assessments, are reported given in Ayyub, Blair, and Patev (2002).

The product of the cost and probability estimates obtained by expert-opinion elicitation is the expected value of the cost of risk of each scenario. The sum of expected values of the cost of risk of all scenarios in each phase gives a profile of costs due to risk for each alternative. The net present value of risk costs over the project's life cycle obtained from this analysis is approximately $\$ 1.5$ million for Alternatives $\mathrm{A}$ and $\mathrm{B}$ and approximately $\$ 3$ million for Alternative $\mathrm{C}$. 
The results show that Alternative $\mathrm{C}$ has approximately double the cost of risk over its life cycle compared with Alternatives A and B. The difference in cost between Alternatives A and B is insignificant given the level of precision of the estimates obtained by expert-opinion elicitation. The main difference between Alternatives A and B is the removal of the earth dike in Alternative A, and this does not provide any measurable benefit in terms of cost of risk.

Areas of future research include sensitivity analysis to examine the effect of allowing for the varying levels of confidence of experts in their estimates. The estimates obtained could be weighted based on the confidence level of the expert, and the significance of the changing weights on the results would be investigated. 


\section{References}

Ayyub, B. M. (1992). "Fault tree analysis of cargo elevators onboard ships," prepared by BMA Engineering for U.S. Navy, Naval Sea System Command, Crystal City, VA.

. (1999a). "Guidelines on expert-opinion elicitation of probabilities and consequences for Corps facilities," U.S. Army Engineer Institute for Water Resources, Alexandria, VA.

. (1999b). "Methods for expert-opinion elicitation of probabilities and consequences for Corps facilities," U.S. Army Engineer Institute for Water Resources, Alexandria, VA.

Ayyub, B. M, Blair, A. N., and Patev, R.C. (2002). "Expert-opinion elicitation for the risk analysis of design-improvement alternatives to the Lindy $\mathrm{C}$. Boggs Lock and Dam," ERDC/ITL TR-02-2, U.S. Army Engineer Research and Development Center, Vicksburg, MS.

Ayyub, B. M., Riley, B. C., and Hoge, M. T. (1996). "Expert elicitation of unsatisfactory-performance probabilities and consequences for civil works facilities," prepared for U.S. Army Engineer District, Pittsburgh, Pittsburgh, PA.

Baecher, G. (1998). "Expert elicitation in geotechnical risk assessment," University of Maryland, College Park, MD.

Bailey, K. D. (1994). Methods of social research, 4th ed. Free Press, New York.

Cooke, R. M. (1991). Experts in uncertainty; Opinion and subjective probability in science. Oxford University Press, New York.

Defense Acquisition University. (1998). "Risk management guide," Defense Systems Management College Press, Fort Belvoir, VA.

Helmer, O. (1968). "Analysis of the future: The Delphi method" and "The Delphi Method-An illustration." Technological forecasting for industry and government. J. Bright, ed., Prentice Hall, Englewood Cliffs, NJ.

Kahn, H., and Wiener, A. J. (1967). The year 2000: A framework for speculation. Macmillan, New York. 
Kumamoto, H., and Henley, E. J. (1996). Probabilistic risk assessment and management for engineers and scientists, 2nd ed. IEEE Press, New York.

Nuclear Regulatory Commission. (1997). "Recommendations for probabilistic seismic hazard analysis: Guidance on uncertainty and expert use," NUREG/CR-6372, UCRL-ID-122160; 1 and 2. Senior Seismic Hazard Analysis Committee, Washington, DC.

Spetzler, C. S., and Stael von Holstein, C.-A. S. (1975). "Probability encoding in decision analysis," Management Science 22(3).

U.S. Army Engineer District, Vicksburg. (1999). "Lindy C. Boggs Lock and Dam improvement plans," Vicksburg, MS.

Wiggins, J. (1985). “ESA safety optimization study,” HEI-685/1026, Hernandez Engineering, Houston, TX. 


\section{Bibliography}

Ayyub, B. M., ed. (1998). Uncertainty modeling and analysis in civil engineering. CRC Press, Boca Raton, FL.

Ayyub, B. M., and Gupta, M. M., ed. (1997). Uncertainty analysis in engineering and the sciences: Fuzzy logic, statistics, and neural network approach. Kluwer Academic Publishers, Boston, MA.

Ayyub, B. M., and Karaszewski, Z. (1997). "Guidelines for probabilistic risk analysis of marine systems," U.S. Coast Guard, Washington, DC.

Ayyub, B. M., and McCuen, R. M. (1997). Probability, statistics, and reliability for engineers. CRC Press, Boca Raton, FL.

Ayyub, B. M., Karaszewski, Z., and Wade, M. (1999). "Probabilistic risk analysis of diesel power generators onboard ships, " Naval Engineers Journal. American Society of Naval Engineers, Alexandria, VA.

Linstone H. A., and Turoff, M. (1975). The Delphi method; Techniques and applications. Addison-Wesley, Boston, MA.

Litai, D. (1980). "A risk comparison methodology for the assessment of acceptable risk," PhD thesis, Massachusetts Institute of Technology, Cambridge, MA.

Modarres, M. (1993). What every engineer should know about reliability and risk analysis. Mercel Decker, New York.

Morgan, M.G., and Henrion, M. (1992). Uncertainty: A guide to dealing with uncertainty in quantitative risk and policy analysis. Cambridge University Press, Cambridge, MA.

U.S. Army Corps of Engineers. (1993). "Guidebook for risk perception and communication in water resources," Report 93-R-13, Institute for Water Resources, Alexandria, VA.

Whitman, R. V. (1984). "Evaluating calculated risk in geotechnical engineering." Journal of Geotechnical Engineering 110(2), 145-88. 


\section{Appendix A Probabilistic Risk Assessment}

Risk studies require the use of analytical methods that model the relationships among subsystems and components in assessing overall system failure probabilities and consequences. A systematic, quantitative approach for assessing the failure probabilities and consequences of engineering systems can be used. A systematic approach allows for the evaluation of complex engineering systems for safety and risk under different operational and extreme conditions. The ability to quantitatively model these systems helps cut the cost of unnecessary and often expensive re-engineering, repair, strengthening, or replacement of the system. The results of risk analysis can also be used in decision analysis for cost-benefit trade-offs. The objective of this section is to introduce needed terminology and methods for performing risk-based technology including risk analysis, management, and communication.

\section{A.1 Risk Terminology}

This section provides definitions that are needed for presenting risk-based technology methods and analytical tools.

\section{A.1.1 Hazard}

A hazard is an act or phenomenon posing potential harm to some person(s) or thing(s), i.e., a source of harm, and its potential consequences. For example, uncontrolled fire is a hazard, water can be a hazard, and strong wind is a hazard. In order for the hazard to cause harm, it needs to interact with the person(s) or thing(s) in a harmful manner. The magnitude of the hazard is the amount of harm that might result, including the seriousness and the exposure levels of people and the environment.

\section{A.1.2 Reliability}

Reliability can be defined in the context of a system or component as its ability to fulfill its design functions under designated operating or environmental conditions for a specified time period. This ability is commonly measured using probabilities. Reliability is, therefore, the occurrence probability of the complementary event to failure resulting in the following expression: 


\section{A.1.3 Failure Consequences}

For an event of failure, consequences can be defined as the degree of damage or loss from some failure. Each failure of a system has some consequence(s). A failure could cause economic damage, environmental damage, injury or loss of human life, or other possible events. Consequences may need to be quantified using relative measures for various consequence types to facilitate risk analysis.

\section{A.1.4 Risk}

The concept of risk is used to assess and evaluate uncertainties associated with an event. Risk can be defined as the potential of losses resulting from exposure to a hazard. Risk should be based on an identified failure scenario, its occurrence probability, its consequences, consequence significance, and the population at risk. However, it is commonly and can be fundamentally measured as a pair of the probability of occurrence of an event, and the outcomes or consequences associated with the event's occurrence. This pairing can be represented by the following equation:

$$
\text { Risk } \equiv\left[\left(p_{1}, c_{1}\right),\left(p_{2}, c_{2}\right), \ldots,\left(p_{x}, c_{x}\right)\right]
$$

In Equation $\mathrm{A} 2, p_{x}$ is the occurrence probability of event $x$, and $c_{x}$ is the occurrence consequences or outcomes of the event. Risk is commonly evaluated as the product of likelihood of occurrence and the impact of an accident:

$$
\operatorname{RISK}\left(\frac{\text { Consequence }}{\text { Time }}\right)=\operatorname{LIKELIHOOD}\left(\frac{\text { Event }}{\text { Time }}\right) \times \operatorname{IMPACT}\left(\frac{\text { Consequence }}{\text { Event }}\right)
$$

In Equation A3, the likelihood can also be expressed as a probability. A plot of occurrence probabilities and consequences is called the Farmer curve.

\section{A.1.5 Uncertainty}

The analysis of an engineering system often involves the development of a system model. The model can be viewed as an abstraction of some aspects of the system. In performing this abstraction, an analyst or engineer must decide which aspects of the system to include and which to leave out. Also, depending on the state of knowledge about the system and the background of the analyst or engineer, other aspects of the system might not be known, thus increasing the overall uncertainty of the system. In these three categories, i.e., abstracted, nonabstracted, and unknown aspects of the system, several types of uncertainty can be present. These models are based not only on probability theory, but also on various combinations of fuzzy-set theory, evidence theory, possibility theory, and various other uncertainty theories. 


\section{A.1.6 Performance}

The performance of a system or component can be defined as its ability to meet functional requirements. The performance of an item can be described by various elements, including reliability, capability, efficiency, and maintainability. The design and operation of the product or system influence performance.

\section{A.1.7 Risk-Based Technology}

Risk-based technologies (RBT) are analytical methods or tools and processes used to assess and manage the risks of a component or system. RBT methods can be classified into risk management (which includes risk assessment/risk analysis and risk control) and risk communication, as shown in Figure A1.

Risk assessment consists of hazard identification, scenario and accident propagation development, event-probability assessment, consequence assessment, and event prevention and consequence mitigation. Risk control requires the definition of acceptable risk and comparative evaluation of options or alternatives through monitoring and decision analysis. Risk communication involves perceptions of risk, which depends on the targeted audience. Hence, methods of risk communication are classified as those directed to the media and the public and to the engineering community.

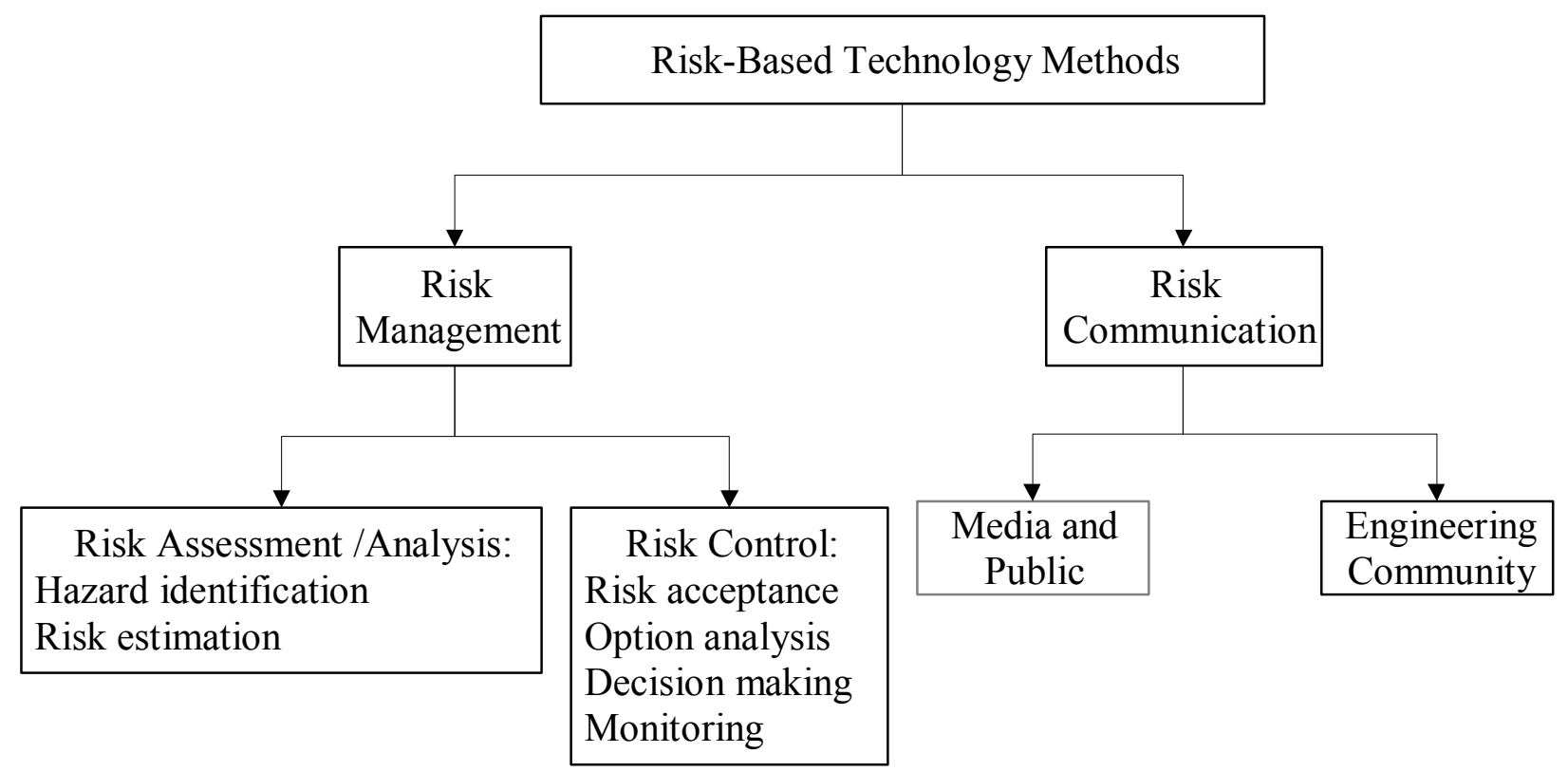

Figure A1. Risk-based technology methods

\section{A.1.8 Safety}

Safety can be defined as the judgment of risk acceptability for the system. Safety is a relative term since the decision of risk acceptance may vary 
depending on the individual making the judgment. Different people are willing to accept different risks, as demonstrated by factors such as location of residence, method of transportation, occupation, and lifestyle. The selection of these different activities demonstrates an individual's safety preference despite a wide range of risk values. Table A1 identifies varying risks for different activities. Figure A2 demonstrates various risks for different industries and activities.

Perceptions of safety may not be true to the actual value of risk. Uncertainty with risk for an activity is often denied by an individual, causing an unwarranted confidence in a person's perception of safety. Rare causes of death are often overestimated, and common causes of death are often underestimated. Perceived risk is often biased by the familiarity of the hazard. Understanding these differences in risk and safety perceptions is vital to performing risk management decisions and achieving effective risk communications.

The significance of the impact of safety perceptions is that decisions are often made on subjective judgments. If the judgments hold misconceptions about reality, the bias will affect the decision. For example, the choice of transportation means by an individual - train, automobile, motorcycle, bus, bicycle, etc. — can stem from a decision concerning many criteria, including such items as cost, speed, convenience, and safety. The weight and evaluation of the decision to select a mode of transportation will rely on the individual's perception of safety, which may vary from the actual value of risk.

\section{Table A1}

Relative Risk of Different Activities

\begin{tabular}{||l|l|l|l||}
\hline Risk of Death & Occupation & Lifestyle & Hobby \\
\hline \hline High $\left(10^{-2}\right.$ to $\left.10^{-3}\right)$ & $\begin{array}{l}\text { Stuntman } \\
\text { Racecar driver } \\
\text { Fireman } \\
\text { Miner }\end{array}$ & Smoking & Skydiving \\
Rock climbing \\
Medium $\left(10^{-3}\right.$ to $\left.10^{-4}\right)$ & $\begin{array}{l}\text { Policeman } \\
\text { Truck driver }\end{array}$ & Heavy drinking & $\begin{array}{l}\text { Canoeing } \\
\text { Driving automobile }\end{array}$ \\
\hline Low $\left(10^{-3}\right.$ to $\left.10^{-5}\right)$ & $\begin{array}{l}\text { Banker } \\
\text { Engineer } \\
\text { Insurance agent }\end{array}$ & $\begin{array}{l}\text { Light drinking } \\
\text { Vaccinations } \\
\text { Radiation }\end{array}$ & $\begin{array}{l}\text { Skiing } \\
\text { Fishing }\end{array}$ \\
\hline
\end{tabular}

\section{A.1.9 Engineering Systems}

A system can be defined as a deterministic entity comprising an interacting collection of discrete elements. The word "deterministic" implies that the system is identifiable. A system shall also be performing some function. A description of a system may be a combination of functional and physical elements. Usually, functional descriptions are used to identify high levels of a system. A system may be divided into subsystems that interact. Additional detail leads to a description of the physical components of the system. 


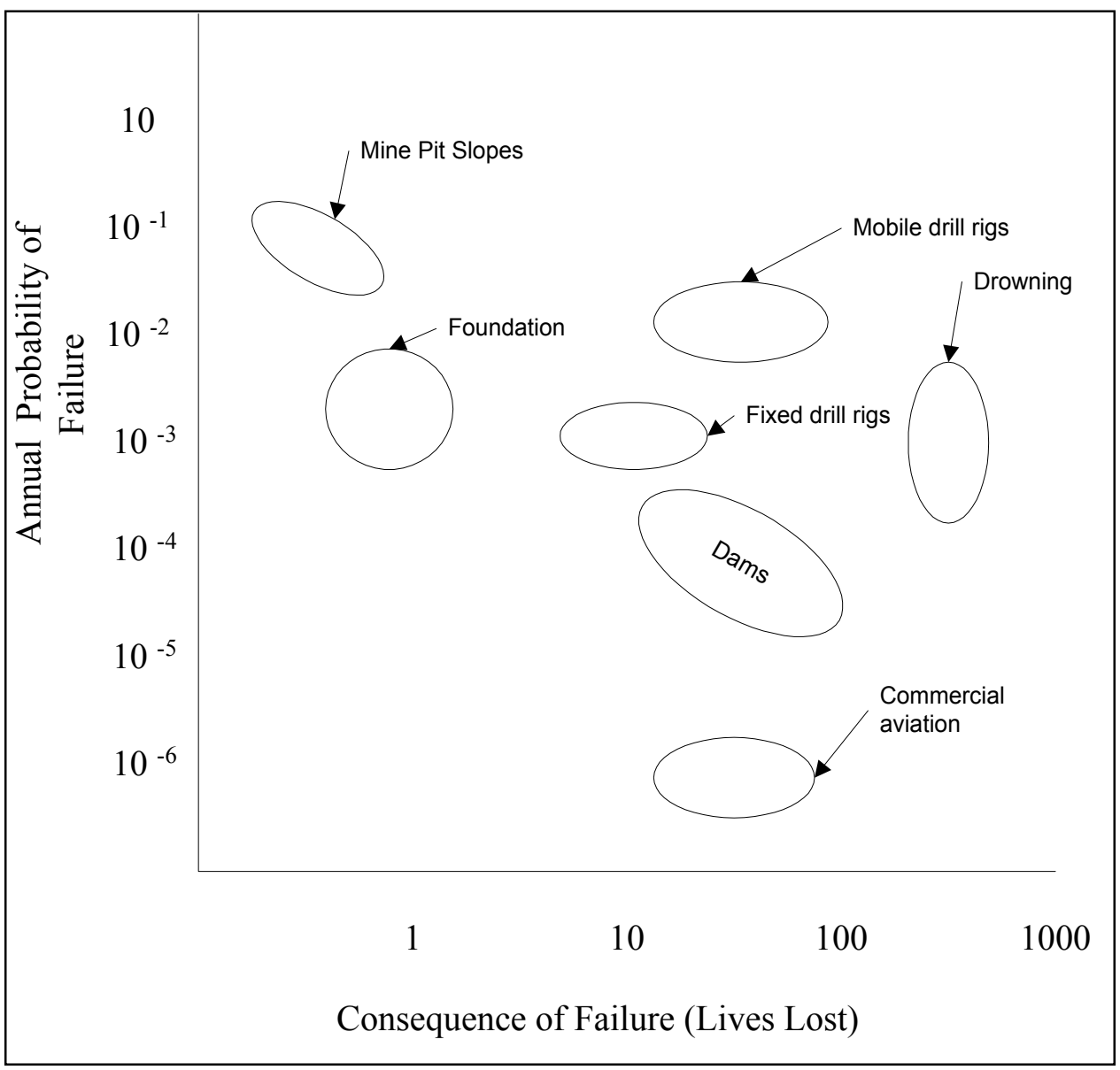

Figure A2. Risk comparisons

\section{A.2 Risk Assessment}

Risk assessment is a technical and analytical process by which the risks of a given situation for a system are modeled and quantified. Risk assessment can require and provide both qualitative and quantitative data to decision-makers for use in risk management.

Risk assessment or risk analysis provides the process for identifying hazards, event-probability assessment, and consequence assessment. The risk assessment process answers three basic questions: (1) What can go wrong? (2) What is the likelihood that it will go wrong? (3) What are the consequences if it does go wrong?

The development of the scenarios for risk evaluation can be created deductively (e.g. fault tree) or inductively (e.g., failure mode and effect analysis or event tree analysis). The likelihood or frequency can be expressed either deterministically or probabilistically. Varying consequence categories may be evaluated including such items as economic loss, loss of life, or injuries. 
Risk assessment requires the utilization of several formal methods, as shown in Table A2. These different methods contain similar approaches to answer the basic risk assessment questions; however, some techniques may be more appropriate than others for risk analysis, depending on the situation.

\section{Table A2 \\ Risk Assessment Methods}

\begin{tabular}{||l|l||}
\hline \hline Method & Scope \\
\hline \hline Safety/Review Audit & $\begin{array}{l}\text { Identify equipment conditions or operating procedures that could } \\
\text { lead to a casualty or result in property damage or environmental } \\
\text { impacts. }\end{array}$ \\
\hline Checklist & Ensure that organizations are complying with standard practices. \\
\hline What-If & $\begin{array}{l}\text { Identify hazards, hazardous situations, or specific accident events } \\
\text { that could result in undesirable consequences. }\end{array}$ \\
\hline $\begin{array}{l}\text { Hazard and Operability } \\
\text { Study (HAZOP) }\end{array}$ & $\begin{array}{l}\text { Identify system deviations and their causes that can lead to } \\
\text { undesirable consequences and determine recommended actions to } \\
\text { reduce the frequency and/or consequences of the deviations. }\end{array}$ \\
\hline $\begin{array}{l}\text { Preliminary Hazard } \\
\text { Analysis (PHA) }\end{array}$ & $\begin{array}{l}\text { Identify and prioritize hazards leading to undesirable consequences } \\
\text { early in the life of a system. Determine recommended actions to } \\
\text { reduce the frequency and/or consequences of the prioritized } \\
\text { hazards. This is an inductive modeling approach. }\end{array}$ \\
\hline $\begin{array}{l}\text { Probabilistic Risk Analysis } \\
\text { (PRA) }\end{array}$ & $\begin{array}{l}\text { Methodology for quantitative risk assessment developed by the } \\
\text { nuclear engineering community for risk assessment. This } \\
\text { comprehensive process may use a combination of risk assessment } \\
\text { methods. }\end{array}$ \\
\hline $\begin{array}{l}\text { Failure Modes and Effects } \\
\text { Analysis (FMEA) }\end{array}$ & $\begin{array}{l}\text { Identifies the components (equipment) failure modes and the } \\
\text { impacts on the surrounding components and the system. This is an } \\
\text { inductive modeling approach. }\end{array}$ \\
\hline Fault Tree Analysis (FTA) & $\begin{array}{l}\text { Identify combinations of equipment failures and human errors that } \\
\text { can result in an accident. This is a deductive modeling approach. }\end{array}$ \\
\hline Event Tree Analysis (ETA) & $\begin{array}{l}\text { Identify various sequences of events, both failures and successes } \\
\text { that can lead to an accident. This is an inductive modeling } \\
\text { approach. }\end{array}$ \\
\hline
\end{tabular}

\section{A.3 Typical Probabilistic Risk Analysis Methodology and Its Levels}

Application of the PRA methodology starts with the definition of initiating events that are considered bad beginnings or accident initiators or failures, and transforms initiating events into risk profiles. The risk management process then follows through initiating-event prevention, initiating-event propagation prevention, onsite consequence mitigation, and offsite consequence mitigation. The PRA methodology includes the following steps for systems with hazardous materials:

- Definition of initiating events.

- Identification of accident sequences and assignment of probability values.

- Distribution of hazardous source based on its terms to the environment.

- Accident propagation, human effects (immediate and latent) and property damage.

- Overall risk assessment and development of risk profiles. 
- Analysis of other risks.

- Risk mitigation through initiating-event prevention, initiating-event propagation prevention, onsite consequence mitigation, and offsite consequence mitigation.

- Uncertainty analysis.

The PRA methodology is commonly termed to consist of three levels, as defined in Table A3. Figure A3 shows potential interactions and dependencies among the various steps of a PRA. An example risk profile based on PRA Level 3 is shown in Figure A4 based on a nuclear release safety study.

\begin{tabular}{|c|c|c|}
\hline \multicolumn{3}{|l|}{$\begin{array}{l}\text { Table A3 } \\
\text { PRA Levels }\end{array}$} \\
\hline PRA Level 1 & PRA Level 2 & PRA Level 3 \\
\hline Accident frequency analysis & Accident frequency analysis & $\begin{array}{l}\text { Accident frequency } \\
\text { analysis }\end{array}$ \\
\hline \multirow[t]{3}{*}{ Accident progression analysis } & Accident progression analysis & $\begin{array}{l}\text { Accident progression } \\
\text { analysis }\end{array}$ \\
\hline & $\begin{array}{l}\text { Source term analysis (toxic } \\
\text { source amount and fraction) }\end{array}$ & $\begin{array}{l}\text { Source term analysis } \\
\text { (source levels and } \\
\text { fraction) }\end{array}$ \\
\hline & & $\begin{array}{l}\text { Offsite consequence } \\
\text { analysis }\end{array}$ \\
\hline $\begin{array}{l}\text { Risk computation (risk profiles } \\
\text { and uncertainties) }\end{array}$ & $\begin{array}{l}\text { Risk computation (risk profiles } \\
\text { and uncertainties) }\end{array}$ & $\begin{array}{l}\text { Risk computation (risk } \\
\text { profiles and uncertainties) }\end{array}$ \\
\hline
\end{tabular}

\begin{tabular}{|c|c|c|c|}
\hline $\begin{array}{c}\text { Accident-Frequency } \\
\text { Analysis }\end{array}$ & $\begin{array}{c}\text { Source-Term } \\
\text { Analysis }\end{array}$ \\
\hline$P\left(A S G_{i} \mid I E_{h}\right)$ & $A S G_{i}$ & $P\left(S T G_{k} \mid A P G_{j}\right)$ \\
\hline$I E_{h}$ & & $A P G_{j}$ & \\
\hline & & \\
\hline
\end{tabular}

Figure A3. PRA steps and their interactions (from Kumamoto and Henley 1996 (C) 1996 IEEE)) 


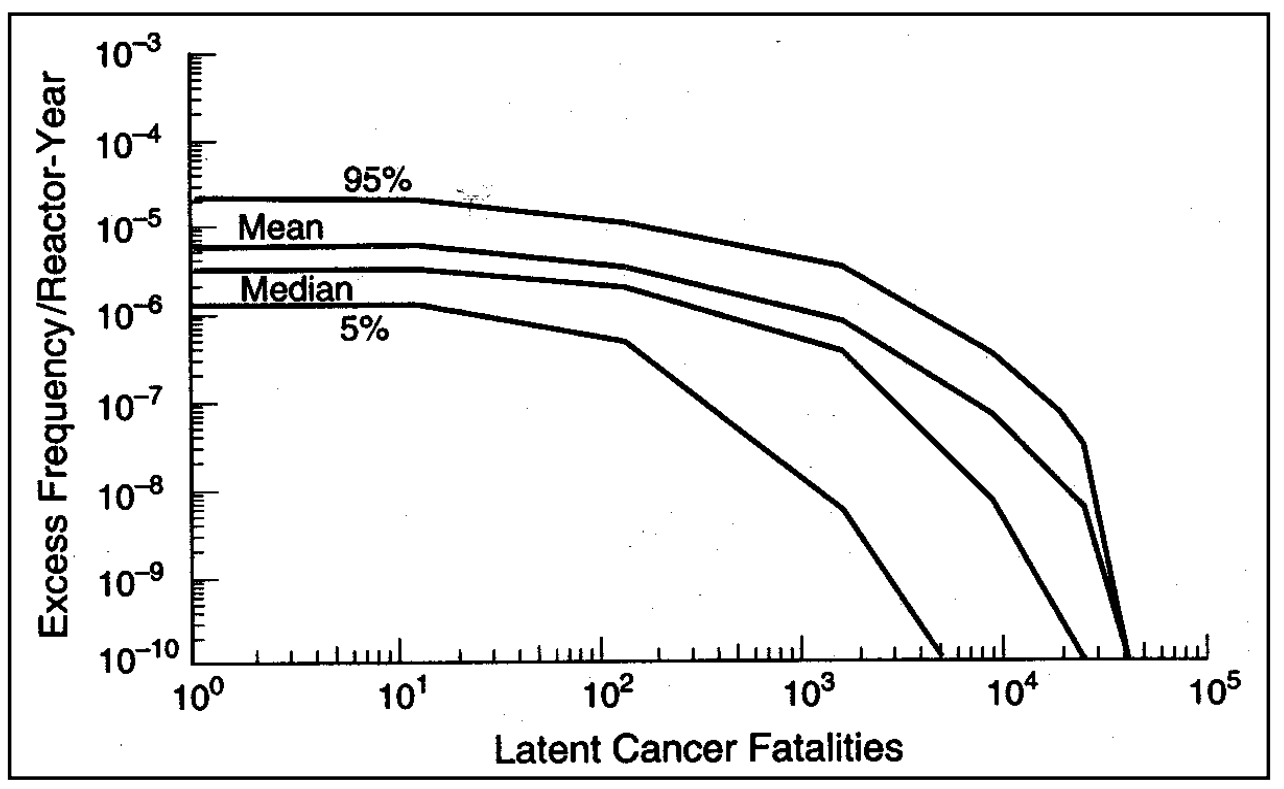

Figure A4. Example risk profile (from Kumamoto and Henley 1996 (@ 1996 IEEE))

\section{A.4 Preliminary Hazard Analysis}

Preliminary Hazard Analysis is a common risk assessment tool with many applications. The general process is shown in Figure A5. In PHA, hazards are defined as initiating events coupled with consequences, and classes of hazards are used such as Classes I to IV (for negligible effect to catastrophic effects, respectively). Initiator groups are defined as events per year or in terms of annual frequency. Initiator groups are generally classified into five groups, ranging from the highest group with frequencies of $10^{10}$ to 10 events per year to the lowest group that has frequencies of $10^{-7}$ to $10^{-6}$ events per year.

The consequence groups can be also considered as five groups from trivial consequences to nonrepairable with fatalities or health effects. This technique requires experts to identify and rank the possible accident scenarios that may occur. It is frequently used as a preliminary way to identify and reduce the risks associated with major hazards of a system.

The PHA method uses an interdisciplinary team in a creative, systematic approach to identify hazards resulting from deviations from design intent. It uses a list of hazards and generic hazardous situations applied to various segments or "nodes" of the system. It also develops recommendations to address those consequences for which safeguards are deemed inadequate by the team. The method requires, if available, codes and standards; previous safety studies; current drawings and flow diagrams; operating procedures; incident history; maintenance, inspection, and test records; and material properties. It also requires a team leader trained in the PHA method and team members with good knowledge of the design and operation of the system being evaluated. 


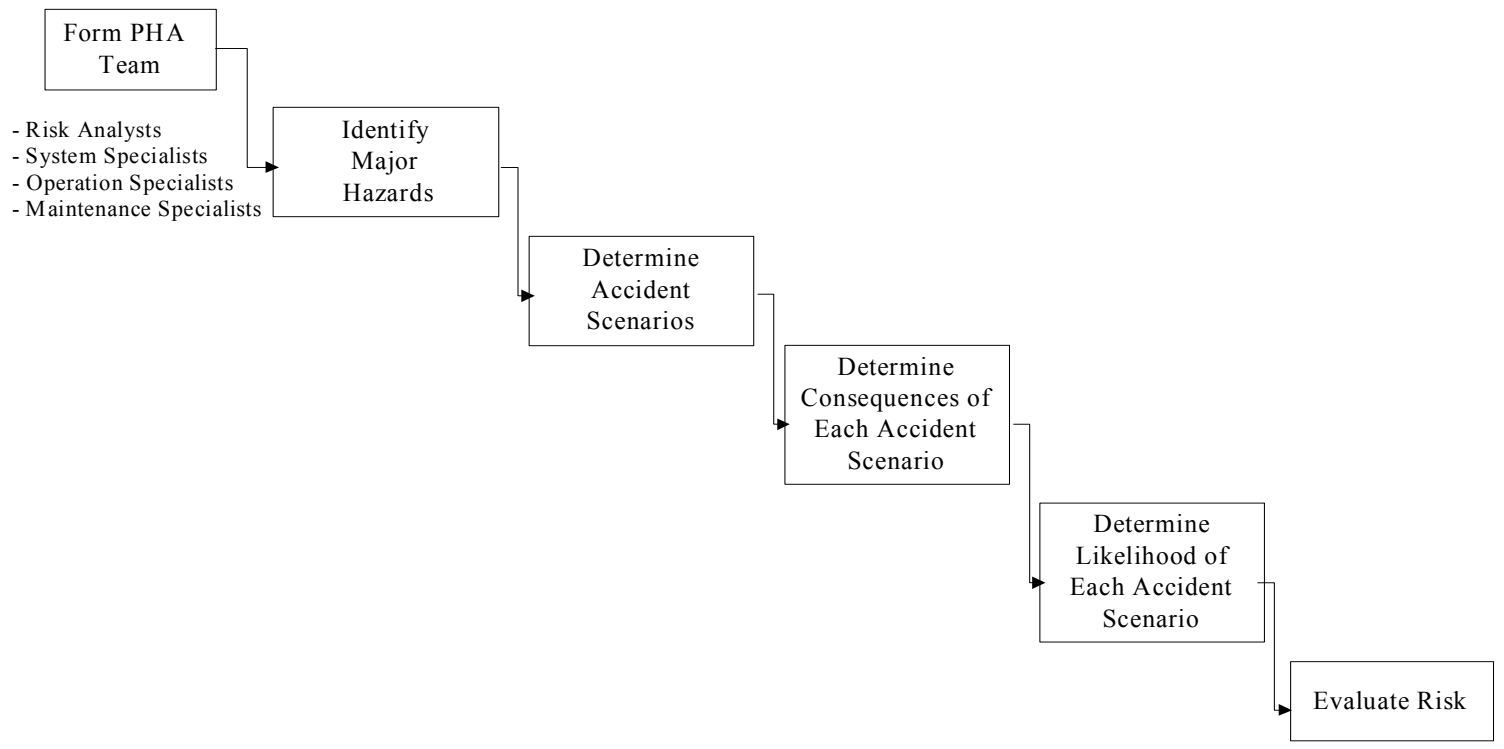

Figure A5. Preliminary hazard analysis process

The PHA methodology can produce findings recorded in the form of hazard scenarios; recommendations for changes in design, procedures, etc.; and recommendations or areas needing further evaluation. Also, it can produce prioritized lists of recommendations based on risk rankings estimated by the team using predetermined guidelines for assigning likelihood and severity of consequences from various scenarios.

Figure A6 provides a PHA methodology that was specifically developed for use by U.S. Navy teams involved in the T-ADC(X) (auxiliary dry cargo carrier) program. The methodology shows detailed steps that are needed to effectively achieve the goals of PHA. The PHA process and results are commonly provided in tables with the following column headings:

- Subsystem or function.

- Mode (or phase of operation).

- Hazardous element (gas, steam).

- Event causing hazardous condition (error, malfunction).

- Hazardous condition.

- Event causing potential accident.

- Potential.

- Effects.

- Hazard class.

- Accident prevention measures (hardware, procedure, and personnel).

- Validation.

The PHA has the advantages that it can be used at the concept design stage by relying on team expertise; it produces lists of risk-ranked hazardous scenarios; it is a creative process for identifying hazardous scenarios that can be readily used in quantitative risk analysis; and it can address both potential safety and productivity losses. However, the methodology has the following limitations: 


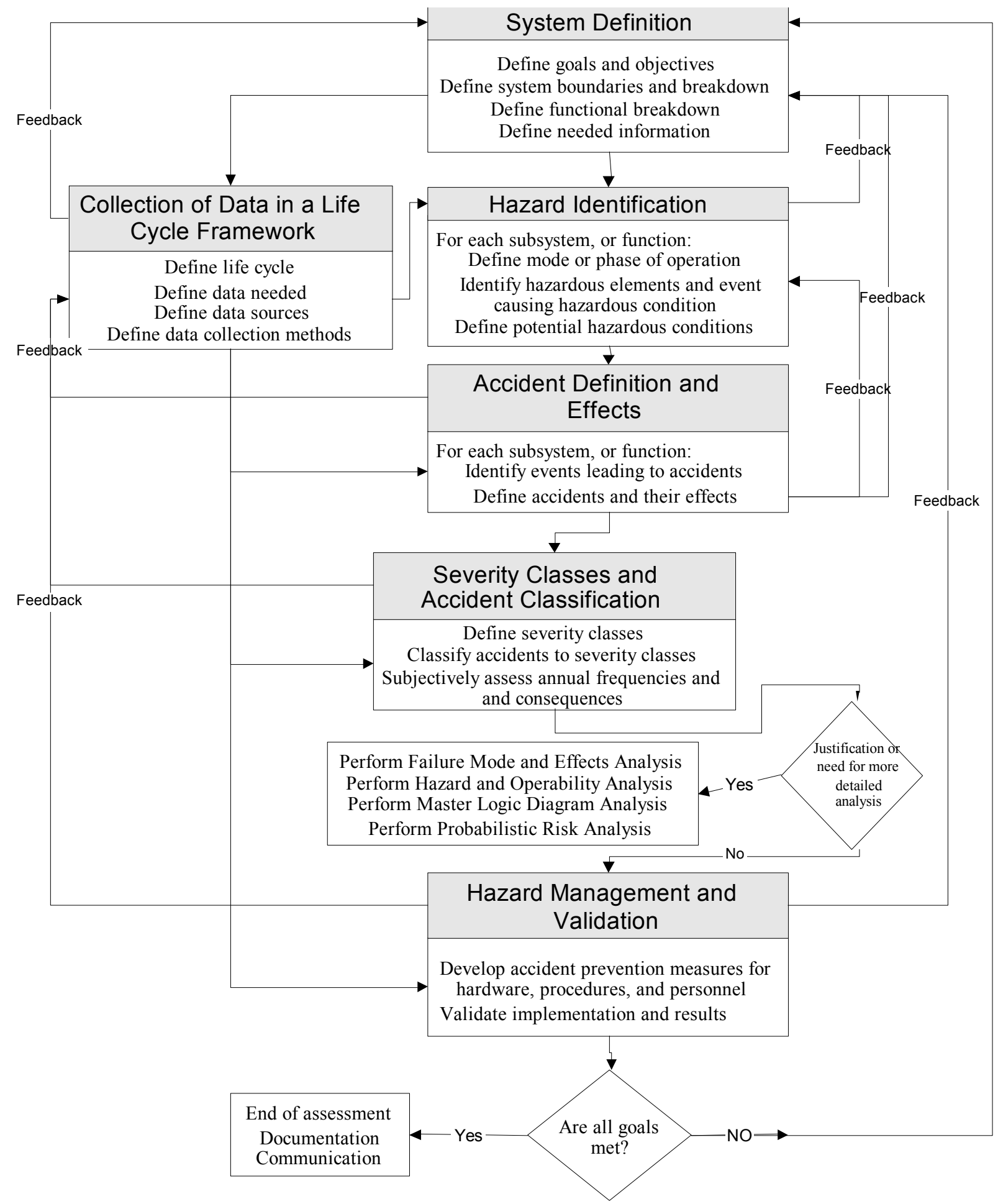

Figure A6. Preliminary hazard analysis methodology 
- It requires an interdisciplinary team of at least four persons, including a scribe and leader trained in PHA.

- It is less systematic than some other qualitative methods (e.g., FMEA or HAZOP analysis) and therefore relies more heavily on team knowledge and commitment to quality analysis.

- If properly applied, PHA can require a level of effort approaching a significant fraction of the time required for HAZOP analysis or a FMEA or PRA.

The PHA methodology has won favor in both the nuclear power and chemical processing industries. The number of marine applications of PHA has increased due to recent commercial accidents that are making regulators, including the U.S. Coast Guard, utilize formal risk assessment tools for design evaluation and approval more frequently than before. 


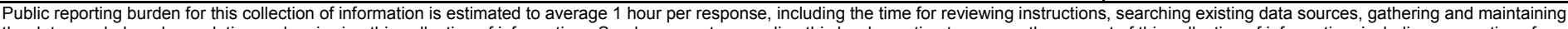

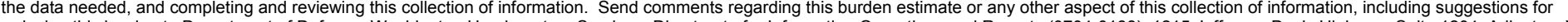

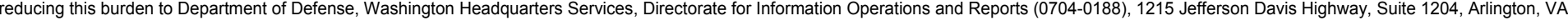

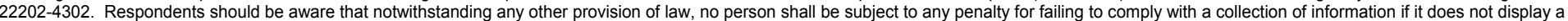
currently valid OMB control number. PLEASE DO NOT RETURN YOUR FORM TO THE ABOVE ADDRESS.

\begin{tabular}{|l|l|l}
\hline 1. REPORT DATE (DD-MM-YYYY) & 2. REPORT TYPE & 3. DATES COVERED (FrOm - To)
\end{tabular}

December 2002

Final report

\section{TITLE AND SUBTITLE}

Risk Analysis of Design-Improvement Alternatives to the Lindy Claiborne Boggs Lock and Dam

\section{AUTHOR(S)}

Bilal M. Ayyub, Andrew Nyakaana Blair, Robert C. Patev

5a. CONTRACT NUMBER

5b. GRANT NUMBER

5c. PROGRAM ELEMENT NUMBER

5d. PROJECT NUMBER

5e. TASK NUMBER

5f. WORK UNIT NUMBER

33236

\section{PERFORMING ORGANIZATION NAME(S) AND ADDRESS(ES)}

8. PERFORMING ORGANIZATION REPORT NUMBER

BMA Engineering, 11429 Palatine Drive, Potomac, MD 20854-1405;

U.S. Army Engineer District, New England, 696 Virginia Road,

ERDC/ITL TR-02-1

Concord, MA 01742-2751

9. SPONSORING / MONITORING AGENCY NAME(S) AND ADDRESS(ES)

10. SPONSOR/MONITOR'S ACRONYM(S)

U.S. Army Corps of Engineers, Washington, DC 20314-1000;

U.S. Army Engineer Research and Development Center, Information Technology

Laboratory, 3909 Halls Ferry Road,

Vicksburg, MS 39180-6199

12. DISTRIBUTION / AVAILABILITY STATEMENT

Approved for public release; distribution is unlimited.

13. SUPPLEMENTARY NOTES

\section{ABSTRACT}

This report summarizes a review and assessment of the Preliminary Hazard Analysis (PHA) for lower lock approach sediment management improvements to the Lindy Claiborne Boggs Lock and Dam. The review assessed the probability of catastrophic failure during the construction and utilization phases of the lock-improvement alternatives.

The Lindy C. Boggs Lock and Dam experiences large water-level fluctuations. To accommodate the large fluctuation of water levels, floating guide walls upstream and downstream of the lock were incorporated into the plans. To retain the riverside lock wall backfill, a concrete "T-wall" was constructed for a distance of $130 \mathrm{ft}(40 \mathrm{~m})$ perpendicular from the lock on the downstream end. Anticipating that sediment would deposit in the navigation channel underneath the downstream floating guide wall, provisions were included in the original plans in the form of an earthen dike and a composite "I-wall" (steel sheetpiling and concrete wall) on top of the dike. The I-wall was connected to the T-wall and continued $130 \mathrm{ft}$ offset from and parallel to the floating guide wall for 1,100 ft (335 m). The purpose of the dike and I-wall was to divert the flow and sediment from the floating guide wall and the navigation channel, thus providing a slackwater lock approach channel. Nonetheless, an average of approximately 310,000 cu yd (237,000 cu m) of silt has been removed annually from the lower lock approach channel at Lindy C. Boggs Lock and Dam. Three alternative improvements are proposed to control this sedimentation: the provision of a new fixed guidewall with dike removal, the provision of a new fixed guidewall with retention of dike, and the barrier extension and use of concrete panels.

\section{SUBJECT TERMS}

Design alternatives

Dams

Delphi process
Expert opinion

Elicitation

Innovative construction
Locks

Navigation project

Preliminary hazard analysis

\section{SECURITY CLASSIFICATION OF:}

\begin{tabular}{|l|l|}
\hline a. REPORT & b. ABSTRACT \\
UNCLASSIFIED & \\
\hline
\end{tabular}

c. THIS PAGE
UNCLASSIFIED

17. LIMITATION OF ABSTRACT
Probabilistic risk assessment

Reliability

Risk analysis

(Continued)

\begin{tabular}{c|l|}
$\begin{array}{l}\text { 18. NUMBER } \\
\text { OF PAGES }\end{array}$ & 19a. NAME OF RESPONSIBLE PERSON \\
\cline { 2 - 2 } 45 & $\begin{array}{l}\text { 19b. TELEPHONE NUMBER (include area } \\
\text { code) }\end{array}$ \\
&
\end{tabular}

Risk assessment Uncertainties 


\section{ABTRACT. (Concluded)}

The U.S. Army Engineer District, Vicksburg, has the requirement to determine the probability of catastrophic failure during the construction and utilization phases of the lock-improvement alternatives, including potential catastrophic damage occurring to the floating guidewall pontoons while they are being removed, transported to and from their temporary storage area, and reinstalled. Catastrophic damage is defined either as the sinking or destruction of any one or all of the pontoons or as sufficient damage occurring to any pontoon so as to require repair or replacement. The probability of this type damage occurring within the navigation channel or the lock chamber, thus shutting down the waterway to barge traffic until the sunken or destroyed pontoon can be removed from the navigation channel, is also required.

The methodology used in this analysis covers key aspects of the PHA process. The proposed risk-based methodology begins with system definition and progresses to defining work tasks for the three alternatives. The tasks in every phase of each alternative are assessed for risk, examining associated initiating events, failure scenarios, consequences, and occurrence probability. Initiating events and failure scenarios are identified and enumerated. Information related to failure probability and consequences is not available from historical records, prediction methods, or literature review and is obtained by expert-opinion elicitation (see companion report entitled "ExpertOpinion Elicitation for the Risk Analysis of Design-Improvement Alternatives to the Lindy Claiborne Boggs Lock and Dam," ERDC/ITL TR-02-2).

The report findings are summarized using tables that include (for each location, system, or procedure) the hazard description, causal factors, hazard effect, initial risk, mitigating control, residual risk, and remarks. The results are provided in terms of initial risk ranking and hazard groups. The various risk-ranking categories are described and discussed. 